NBER WORKING PAPER SERIES

\title{
BUSTNESS CYCLES AND THE EXCHANGE RATE SYSTEM: SOME INTERNATIONAL EVIDENCE
}

Marianne Baxter

Alan C. Stockman

Working Paper No. 2689

\author{
MATIONAL BUREAU OF ECONOMIC RESEARCH \\ 1050 Massachusetts Avenue \\ Cambridge, MA 02138 \\ August 1988
}

This paper is a revised version of the paper "For what Does the Exchange Rate System Matter?", prepared for the University of Rochester and Iniversity of Western Ontario Conference on Exchange Rate Variability, held in Toronto, Canada on September 24-25, 1987. We wish to thank Leonardo Leiderman, Larry Sumers, participants at the Rochester-Western-Ontario conference, at an NBER conference on the EMS, and at seminars at Brown and Yale for helpful comments and criticisms. Financial support was provided by the National science Foundacion and the Sloan Foundation. This paper was revised while Baxter was a Ford Fellow at the National Bureau of Economic Research. This research is part of NBER's research program in International Studies. Any opintons expressed are those of the authors not those of the National Bureau of Economic Research. 


\section{NBER Working Paper \#2689 \\ August 1988}

BUSINESS CYCLES AND THE EXCHANGE RATE SYSTEM:
SOME INTERNATIONAL EVIDENCE

\section{ABSTRACT}

This paper investigates empirically the differences in time-series behavior of key economic aggregates under alternative exchange rate systems. We use a postwar sample of 49 countries to compare the behavior of output, conauption, trade flows, government consumption spending, and real exchange rates under alternative exchange rate systems (pegged, floating, and systems such as the EMS). We then examine evidence from two particular episodes, involving Canacia and Ireland, of changes in the exchange rate system. Aside from greater variability of real exchange rates under flexible than under pegged nominal exchange rate systems, we find little evidence of systematic differences in the behavior of other macroeconomic aggregates or international trade flows under alternative exchange rate systems. These results are of interest because a large class of theoretical models implies that the nominal exchange rate system has important effects on a number of macroeconomic quantities.

Mariane Baxter Department of Economics University of Rochester Rochester, NY 14627

\author{
Alan C. Stockman \\ Department of Economics \\ and NBER \\ University of Rochester \\ Rochester, Ny 14627
}


This paper investigates the manner in which the statistical character of business cycles depends on a country's choice of exchange rate system. We have two objectives in this paper. First, ve vish to determine hou the choice of exchange rate system affects the character of economic fluctuations. Second, ye seek to develop a set of facts about the character of international business cycles that can help guide subsequent international evidence on output, consumption, trade flows, and real exchange rates and ve compare the behavior of these series under the Bretton Woods pegged exchange rate system with that under the (limited) floating rate system that has prevailed since 1973. Then we examine particular episodes in which a country changed its exchange rate system at a time other than 1971-73.

The study of business cycles and their international transmission is one of the oldest topics in economics; the first detailed statistical analyses of business cycles were undertaken in the 1920 s by the National Bureal of Economic Research under the leadership of Wesley Clair Mitchell. Escheuing. traditional statistical methodology, Mitchell and his collaborators developed new methods for summarizing business cycle phenomena. They found that the empirical regularities of economic fluctuations lay not in the length of cycle or its ampitude, but rather in the patterns of comovement and relative amplitude of economic variables.

Mitchell investigated the international correiation of business cycles in his book Business Cycles: The Problem and Its Setting (1927). He concluded that business cycles are positively correlated across countries and especially countries with highly developed economies, and particularly those with vell developed financial markets. He also found that business cycles vere becoming more highly correlated across countries over time and he attributed this result to the growth in international financial linkages. 
Dskar Morgenstern (1959) carried out detailed analyses of international business cycles, focusing specifically on financial markets, and raised the guestion of whether the international character and transmission of cycles depended on the exchange rate syster. At that time, experiences with alternative exchange rate systems vere considerably more limited than now, vith data froth the 1970 s and 1980 s available.

More fecently, the neoclassical approach to studying business cycles was motivated by the perspective that "business cycles are all alike". " Lucas states that "There is, so far as I know, no need to qualify these observations [about cycles] by restricting them to particular countries of time periods: they appear to be regularities common to all decentralized market economies."2 Explaining these patterns of co-movement and relative amplitude has become the chief aim of recclassical business cycle theory. Neoclassical business cycle research has also sought to improve on the methods of Mitchell and his collaborators, by using formal statistical procedures, so that "results are Ieplicatabie and criticizable at a level at which Mitchell's are not." Lucas (1981, p.236, ff. 4). Development of statistical procedures and stylized facts has led raturally to efforts to develop quantitatively restricted models that can reproduce the observed covariation of economic aggregates.3

Lucas (1981), p. 218. Italics in original.

2ibid, page 218 .

3See, for example, Hodrick and Prescott (1980). Kydland and Prescott (1982), - Long asd Plosser (1983), Hansen (1985). Prescott (1986). and King, Plosser. and Rebelo (1987). 
In this paper, ve follow the original NBER strategy of describing the character of cycles thile abstaining from imposition of a specific theoretical structure, but we employ modern time series methods. Specifically, the paper asks whether, from a statistical point of view, it makes sense to consider the fixed and flexible-rate systens as a single unit when processing the data for comparison with theoretical models. Many theories of the international transmission of shocks (real shocks or shocks due to monetary policy) have the implication that the transmission process depends critically on the exchange rate system in place. An empirical implication of these thecries is that-holding constant the sources of exogenous shocks and their stochastic processes-the variances and covariances of economic aggregates will depend on the exchange rate system. While some attention has been paid to the empirical relations betueen the variability of real exchange rates and the exchange rate system, 4 ve know of no systematic empirical studies of the relationship between the exchange rate system and other macroeconomic variables. This paper, and a related paper by Baxter (1988) are intended to fill this gap.

The paper proceeds as follows. Section It uses data from tuenty-three OECD countries and twenty-one non-OECD countries to examine vhether the statistical behavior of economic aggregates differs systematically across exchange rate systems. We ask, first, whether pre-1973 behavior-corresponding roughly to a period of pegged exchange rates-differs from post-1973 behavior-corresponding to a period of floating rates, albeit with some government intervention. Second, we ask whether courtries on fixed

\footnotetext{
4See, for example, Stockmar (1983) and Mussa (1987).
} 
consumption and industrial production. Third, we examine the cross-regime volatility of real exports, imports, and the real exchange rate. The sample of countries includes the previously-analyzed OECD countries together with about twenty additional countries, wost of which are LDC's. Because the post-1973 sample inciudes countries on both fixed and flexible rates, we can potentially separate effects due to a nation's exchange rate system from a "post-1973 effect" due to other changes in the world economy. Finally, we turn to the question of government behavior under alternative exchange rate systems. We examine the variability and cross-country correlation of government consumption expenditures.

We consider three comnon detrending procedures, though we do not always report results with all three procedures except there those results differ substantially. The three procedures are (i) taking differences (growth rates), (ii) removing deterministic linear trends, and (iii) using the Hodrick-Prescott (1980) filter. Figure 1 plots the squared gain (transfer function) for these filters against frequency. For time-series vith positive serial correlation (as in our data) most of the power is at the lowest frequencies. The differencing filter permits the smallest proportion of Iow frequency components to pass through, yith the HP filter trangferring more, and the ligear trend filter transferring the most. For highly autocorrelated series the power is concentrated at the lov frequencies where the differencing filter and HP filter are very similar, and results using that filter are not reported here.

\section{Industrial Production}

Table 1 and Figures 2 and 3 give the standard deviation of detrended industrial production for fourteen DECD countries and the correlation of 
these countries' industrial production with that of the U.S. Two derrending methods are used: a single linear trend and differencing. For the question of whether volatility has changed, the two filters give the same ansuer: volatility has generally increased. In the post-1973 period, about three-quarters of the countries experienced an increase in the volatility of industrial production. The increase was as likely to occur in previously high volatility countries as in low volatility countries.

Figures 4 and 5 plot the correlations of industrial production in each country uith that of the U.S., and yield somewhat different conclusions depending on the detrending method. With a linear trend removed, it appears that there is no significant change in the average correlation with the U.S.: the countries plot about equally on either side of the 45 degree line.

For the differenced data, however, there is a marked tendency for this correlation to fall in the post-1973 period; only Japan and Greece experienced an increase in corfelation with the U.S. (and the Japanese result may be due to that courtry's recent lovering of barriers to trade.) Thus it appears that the general decrease in cross-country correlation in industrial production has taken place in the relatively higher frequencies emphasized by the differencing filter. 7

Figure 6 shows the average quarterly growth rates for the fixed and flexible rate periods; this graph shows clearly the effect of the "slowdoun" of the 1970's and 1980's-every country's grovth rate is lover in this period.

${ }^{7}$ This issue could be addressed directly by estimating the cross-country correlations at distinct frequency bands, using techniques developed by Engle (1974). 
Finally, the average grouth rates of consumption in the fixed and flexible rate periods mirror the earlier results for industrial production: there is a marked slowdown in the post-1973 period.

Tables 3 and 4 show the cross-correlations of consumpion with industrial production for the single linear trend filter and the differencing filter. As with the U.S. data, the zero-order correlation is higher for the linearly-detzended data. However, the level of this correlation varies uidely among the eight countries in the sample: for the fixed rate system and the lineer trend filter this correlation ramges from a high of .989 for Japan to a lov of .348 for France. A similarly wide range is observed for the differenced data. Comparing the fixed and flexible rate systems, a general increase in correlatedness in the flexible rate period is observed between consumption and industrial production for both detrending methods. For linearly detrended data, six of the eight countries experienced increases in correlatedness, while for the differenced data, seven of the eight experienced increases. Further, in the case of the linearly detrended data, the correlation between consumption and lagged output seems more persistent in the flexible rate period: large correlation coefficients are found in many countries as $f$ ar back as sever lags (aimost two years).

These results reinforce the emerging picture of the post-1973 period as a period in which cyclic movements are more country-specific than in the previous, fixed-rate period. As mentioned earlier, this is surprising in view of the world-wide oil shocks of the 1970's. It is also surprising since the flexible-rate period has been characterized by dramatic increases in the openness and liquidity of international financial markets. Yet the 
within-country correlation of consuption and output has actually risen during this period for most of the countries examined.

While differences in national policies may help explain the decline in cross-courtry correlatedness in output, it does not explain the increase in the correlation between cyclic movements in consumption and changes in output. To the extent that cyclic movements in national output are temporary and in particular because cross-country correlation of output has decreased (so that the world interest rate should not be highly correlated with a single country's output), one would expect a decreased correlation of within-country consumption and output. Yet we find exactly the opposite.

\section{Exports, imports, and the real exchange rate}

We turn next to analysis of exports, imports, and the real exchange rate. The sample of OECD countries is expanded to include about tuenty other countries, many of them LDC's. Table 5 catalogues exchange rate systems by country and by year. Of the 49 countries in the post-1973 sample period, 14 were fixed to the doliar throughout, 17 floated throughout ${ }^{9}, 7$ are members of the EMS, and 11 had some other arrangement or changed the exchange rate system several times. Prior to 1973 , all countries vere on primarily fixed rates (although two, Canada and Korea, floated for short periods in the pre-1973 period).

\footnotetext{
gSome countries which actively intervened in the market for their curfency are nonetheless included in the "floating rate" group. All countries manage their exchange rates to some degree, so tine division betueen "floating" and "acjustable peg" is, to a large extent, arbitrary. We have chosen to classify countries according to their stated policies, as reported to the International Monetary Fund.
} 
fixed to the dollar until 1981, Somalia, fixed until the end of 1982, and Mexico and Israel, which have floated vith some intervention throughout).

Thus for the OECD countries, there is some evidence that membership in the EMS is associated with lover volatility of imports and exports. Of course, whether this is due to the exchange rate system or other factors such as EEC trade policy is an open question.

For the non-GECD countries, there does not seen to be any strong correlation between the choice of post-1973 exchange rate system and the volatility of imports and exports during that period. Countries choosing to remain fixed to the dollar seem somevhat more likely to experience increased trade volatility than countries choosing to allow their exchange rate to float. This is surprising since real exchange rates have become more volatile in the post-1973 period, and the real exchange rate volatility is commonly thought to be associated with floating rate systems. He therefore turn rext to an investigation of real exchange rate volatility, and its relationship to the exchange rate system and volatility in real exports and imports.

Table 9 displays F-statistics for the hypothesis of no significant change in the volatility of the real exchange rate between the fixed and flexible rate periods. A country's real exchange rate is calculated as P/eP* vhere $P$ is the country's consumer price index, P* is the CPI for the United States, and $e$ is the country's exchange rate against the U.S. dollar. Four countries experienced significant decreases in real exchange rate variability in the post-1973 period: India, Yugoslavia, and the Philippines, which vere on floating exchange rates; and Liberia, which was fixed to the dollar.

By contrast, thirty of the forty-four countries for thich data are : available experienced significant increases in real exchange rate variability 
in the post-1973 period. Surprisingly, of the four DECD countries which escaped an increase in real exchange rate variability, none is a member of the EMS. Of the seven non-DECD countries vith no significant change in real exchange rate variability, four were on primarily fixed rates in the post-1973 period (Ecuador, which floated only in 1983. El Salvador, Haiti, and Honduras) and two vere on floating rates (Israel and Tunisia).

Table 10 contains t-tests for the hypothesis of no change in the growth rate of the terms of trade preand post-1973. Only two countries show significant changes, both decreases: El Salvador and Guatemala. Both countries were fixed to the dollar for most of the post-1973 period.

Thus, the post-1973 period is one characterized by general increases in volatility of courtries'. Teal exchange rates; this corroborates findings by Mussa (1996) and many others. Countries on fixed rates (or cooperative schemes like the EMS) appear as likely as those with pure floats or other, intermediate regimes to experience these increases in volatility, though Stockman (1973) provides evidence that the magnitude of the increase in volatility is larger for floating rate countries, Of the thirty countries with significant increases in real exchange rate variability, only ten had increases in export and/or import volatility. Of the seven non-OECD courtries vith no increase in real exchange rate variability, two had significant increases in real trade volatility. Thus, about one-third of the countries experienced significant increases in volatility of exports or imports, but this proportion does not seem to be related either to the exchange rate system or to an increase in real exchange rate variability.

Tables 11 and 12 summarize our findings on the relationship between the volatility of real trade activity, volatility of the real exchange rate, and the exchange rate system. (These tables only include countries for which 
data were available both for real trade activity and the real exchange rate.) The most striking fact about these two tables is that charges in real trade variability and real exchange rate varjability appear to be independent of each other. Further, changes in trade variability and real exchange rate variability appear to be independent of the exchange rate system. The only notable difference is that OECD members appear slightly less likely than non-0ECD members to have increases in real trade variability.

\section{Government Corsumption}

It is possible that the exchange rate system affects the response of macroeconomic and international trade aggregates to external disturbances, but that governments altered their macroeconomic policies in just the right way so as to eliminate the systematic differences in macroeconomic performarce, across exchange rate systems, that we have sought to uncover. There have been ciear differences in some governmert policies over the periods ve have associated with pegged and floating exchange rates. The differences across exchange rate systems ir the behavior of nominal variables such as monetary aggregates and nominal price levels has been studied elsewhere (see, e.g. Darby and Lothian, 1988). We examined the behavior of annual real government consumption (as reported by the DECD, and deflated by consumer price indexes) for 22 of our countries, over the periods 1960-72 and 1973-85. Table 13 shous the standard deviations of the grorth rates of real government consuption in the pegged exchange rate period (SDPEG), the floating rate period (SDFLT), and the difference between these tro (SDDIF). In 16 of the 22 countries, the standard deviation fell in the floating rate period. The average fall, excluding the tuo largest changes (France and 
Denmark), was .0067 , which is a fall of about $1 / 4$ from the mean under pegged rates of .026 .

Table 14 reports, and Figure 7 graphs, a dramatic change across these periods in the average correlation between the grouth rate of real government consumption in each country with the growth rates of real government consumption in the other 22 countries. Grouth rates in real government corsumption becane much more highly correlated across countries in the flexible exchange rate period. The average correlation in the pegged-rate period was .04 , while the average correlation in the floating rate period vas .30, and, except for Switzerland, each country showed a positive average correlation (and the average correlation rose for every country except Switzerland). Whether this change in the cross-country correlation of the government consumption gronth rates had little effect on the macroeconomic aggregates we have studied, or whether it had effects that helped offset the effects of the change in exchange rate system, is an important question for future research. Greater correlation across countries in government consumption spending would seem unable to account, however, for our earlier finding that business fuctuations seem to have become more nation-specific. If anything, our results on government consumption magnify the problem.

\section{Two Episodes of Change in the Exchange Hate System}

This section studies tro episodes of change in the exchange rate system that did not occur in the 1971-73 period. These tuo episodes are (i) the switch in the currency to which Ireland pegged its currency, from the U.K. before 1979, and Germany (via the EMS) after 1979, and (ii) the Canadian float against the U.S. dollar from 1951-62, which begar again in 1970 . 
Ireland

Ireland pegged its currency to the British pound until January 1979, when it joined the joint float of continental currencies that became the European Monetary System in March 1979.10 After Jantary 1979, the Irish pound floated with respect to the British pound but vas effectively tied, within EMS limits, to the German mark. Figure 8 shows the nominal exchange rate between Ireland and Britain from 1960 through 1985 , and the real exchange rate calculated as the exchange-rate-adjusted ratio of consumer price indexes in the two countries. (Using alternative price indexes has virtually no impact on the results.) The real and nominal exchange rates behave similarly, especially after 1979, and the variability of the real exchange rate is much greater when the two currencies float against each other. Figure 9 show the real and nominal exchange rates between between Ireland and Germany. Again, the real and nominai exchange rates tend to mirror each other, but the relationship is less strong in the post-1979 feriod when Ireland was pegging to Germany.

Table 15 shows the standard deviation of the real exchange rate (in levels) of Ireland vs. the U.K, and Vs. Germany. The post-1973 period as a whole is characterized by much higher volatility of real exchange rate.

The precise conclusions one draws about changes in real exchange rate variability depend an the filter used. Because the proper model for the real exchange rate is subject to controversy, ve report results for several alternatives. Lookigg at levels of real exchange rates or using data vith linear trends removed, the standard deviation for Ireland Vs, the U.K. is

10Mussa (1986) uses this episode as evidence on the relationship betveen. the exchange rate system and the variability of the real exchange rate. 
higher than that for Ireland vs. Germany for every time period. With the difference filter, only during the period 1973-78 during thich Ireland floated against Germany is this reversed. Hitb levels or a single time trend removed, the standard deviation for the Irish-U.K. Case did not rise much in the 1973-78 period vith a bilateral peg, though it rose more substantially if the differencing filter or separate time trends are employed. For the Ireland-U.K. case, the floating rate period of $1979-85$ is characterized by much greater volatility than during earlier periods. Using levels or data filtered by a single time trend, the Irish-German real exchange rate actually shows greater variability after 1979, when Ireland joined the EMS, than during the floating rate period from 1973-78. This conclusion, though, is reversed if the differencing filter is used.

Figure 10 shous quarterly grouth rates of the real exchange rates betueen Ireland and Germany (the solid Iine) and between Ireland and the U.K. (the dashed line.) The growth rate of the real exchange rate of Ireland against both countries is more volatile in the post-1973 period. Within the period from 1973-1979, when Ireland vas pegging to the U.K., the real exchange growth rate for Ireland vs. the U.K. is less volatile than that computed for Ireland vs. Germany. In the post-1979 period, when Ireland was effectively pegged to Germany, the ordering is reversed: the volatility of Ireland vs. Germany it smaller than for Ireland vs, the U.K. Thus, volatility in the real exchange rate is clearly linked to exchange rate regime.

A natural next question is vhether the increased volatility in the real exchange rate is wirrored in other real quantities. Table 16 gives the standard deviation of Ireland's real exports and imports for linearly detrended and log-differenced data. For the differenced data, the volatility 
of real imports and exports appears to be the same in all time periods. For the linearly detrended data, the flexible-rate period is characterized by increased volatility in both imports and exports, with the post-1979 period being characterized by a large increase in volatility, especially in imports. This mirrors the post-1979 increase in volatility of the real exchange rates discussed above. But when a single linear trend is removed, real exchange rate volatility appears to increase post-1979 for Ireland against both Germany and the U.K. . These results casts doubt on the hypothesis that the increases in real exchange rate volatility and trade volatility (in the detrended case) in the post-1979 period vere a result of the suitch in the exchange rate system. However, this conclusion (as discussed above) depends eritically on the filter used for the real exchange rate.

Continuing with the line of investigation pursued in earlier sections, we investigate the cross-country variation and correlatedness of industrial production. Many theoretical models predict that the exchange rate system affects the macroeconomic effects of various government policies. The Mundell-Fleming model, for example, predicts different effects of government policies under pegged and floating exchange rate systems. Many of these madeis can be formulated to predict that the excharge rate system between two nations affects the relative behavior of real output in those nations, unless government policies are altered in very opecial vays to precisely offset the effects of the change in the exchange rate system. He proceed now to examine the relative behavior of real ontput in pairs of coutaries that have changed erchange rate systems, to determine whether there is any associated change in relative output growth rates, A finding that there vas no structural change in the process deteraining relative levels of real * output does not necessarily imply that the exchange rate system is irrelevant 
for relative output, because it is possible that government policies vere adjusted precisely so as to offet the effects of the exchange rate systen on real output. Although a more complete model of the output effects of various policies and a description of their changes when the exchange rate system changes vould be required to examine this issue, the data analysis ve conduct in this paper is of interest because it places restrictions on the effects of the exchange rate system, the output effects of govermment policies, and the changes in policies across exchange rate systems. Table 17 gives standard deviations of industrial production and cross-country correlations by subperiod, for linearly-detrended and log-differenced data. The standard deviations of industrial production for the three countries seem roughly equal and do not seem to vary aver the three subperiods studied. This result is independent of the detrending method. The correlation between the industrial production measures for Irelasd and Germany are bigher than the correlation between Ireland and the $U . K$. for every time period and for both detrending methods. Further, when Ireland switched from pegging against the U.K. to pegging against Germany, the correlation between Irish industrial production and U.K. industrial production actually rose (more dramatically for linearly detrended data), while the corfelations between Irelard and Germany remained essentially unchanged.

To investigate this further, ve examine the difference between the growth rates of industrial production in Ireland and in Germany, denoted $y(I, G)$. It can be tell represented by a second-order autoregressive process with seasonal dumies over the initial period of pegged exchange rates, 1961 I through $1972 \mathrm{IV}$, 


$$
\begin{gathered}
y(I, G, t)=\frac{-.05-.18 y(I, G, t-1)}{(.01)(.14)} \frac{-.38 y(I, G, t-2)}{(.14)} \\
\text { adj. } R^{2}=.60 \quad D H=2.10 \quad s e=.038
\end{gathered}
$$

(vhere seasonal dummy variables vere also included in the estimated equation). This equation is stable over the $1961-72$ period. The residuals show no signs of autocorrelation; the chi-square statistic for testing the hypothesis that the first four autocorrelatior coefficients of the residuals are zero is 4.14 , which is vell below the critical value of the chi-square statistic with four degrees of freedom at the 10 percent level. Similarly. the residuals shot no signs of heteroscedasticity, and chi-square tests indicate the absence of ARCH effects, for any number of lags in the ARCH specification, at the 10 percent level. There is, hovever, indication that the disturbances are rot Gaussian because of excess kurtosis. The same coeficient estimates, to two decimal places, are obtained if the difference in growth rates of output is replaced with the difference in deviations of the $\log$ of output from linear trends, because the two filters give measures of relative output that have a simple correlation coefficient of .9999 . While linear detrending, rather than taking grouth rates, affects the time series properties of output in each country alone, relative output in the two countries is virtually unaffected by which of these filters is employed.

When the equation above is estimated over the longer period $1961 \mathrm{I}$ through $1978 \mathrm{IV}$, which includes both the initial pegged exchange rate period and the period during which the Irish pound and British pound vere pegged to each other but vere jointly floating against the Deutschmark, the results are (also vitb seasozal dumies included) 


$$
\begin{aligned}
& y(I, G, t)=\frac{-.05-(.01)(.11)}{(.01)(I, G, t-1)-.35} \text { y }(I, G, t-2) \\
& \text { adj. } R^{2}=.70 \quad D W=2.10 \quad \text { Ee }=.035
\end{aligned}
$$

and a chi-square test for the bypothesis that the six coefficients are identical across the sample periods 1960I-72IV and 1973I-78IV yields a test statistic of 6.17 , thich is well belou the critical value of the chi-square statistic with six degrees of freedom at the 10 percent level. Equation (2) passes other specification tests as vell: there is no indication of heteroscedasticity, and a chi-square test based on the third and fourth momerts of the distribution of residuals yields a statistic of 3.30 , vhich is below the 10 percent critical value of the chi-square statistic $v i t h$ two degrees of freedom. Tests for higher-order autocorrelation of residuals also indicate absence of serial correlation in the residuals. In sumary, equation (2) gives a statistical representation of relative real output growth rates (or deviations from trend) in Ireland and Germany that is stable over the time perlod from 1960 to the end of 1978 , wihch includes periods vith both exchange rate systems.

However, when the equation 'is estimated over the entire period 1960I-85IV, the estimated coefficients change substantially, and a chi-square test for the hypothesis that the six coefficients are identical over the periods 1960I-78IV and 1979I-85IV yields a statistic of 22.53 , which is above the critical value of the chi-square vith six degrees of freedom even at the .001 level. There is, as a consequence, evidence of a structural shift in the time series process describing relative output in Ireland and Germany around the time when Ireland joined the EMS with limited exchange rate 
flexibility against Germany. Whether this shift is an effect of the change in exchange rate systen, a cause of its change, or unconnected with the exchange rate system cannot be determined from this work. However, we can investigate issues of timing by studying when the break in the relative output process occurred. For a given sample, consider a test of the hypothesis that the next observation is generated by the sare process as the preceeding observations, which is a Chov test with the second subperiod consisting of a single observation. Consider a sequence of these test statistics. Figure 11 shows a graph of timis sequence, normalized so that the 5 percent critical value can be represented as a constant. The structural breaks in the relative output process appear to occur after the change in the exchange rate system, and the change ir. the structure is dominated by observations after 1984I. Similarly, a sequence of Chow test statistics, each for testing the hypothesis that all of the remaining observations through $1986 I V$ are drawn from the same process that generated the previous observations, reaches a peak in 1984II. Consequently, although there is evidence of a structural break in the process describing relative real output in Ireland and Germany, the evidence suggests that this break occurred around 1984, and so was probably unconnected with the change in the exchange rate system in the first quarter of 1979. This conclusion is also consistent with the evidence indicating the absence of a structural change in the process around 1973, when the first change in the exchange rate system occurred.

Now turn to the difference between quarterly growth rates of industrial production in Ireland and Great Britain, denoted $y(I, G B)$. The time series representation of this series shows clear signs of structural change during the period 1962I-1985IV. For the subperiod vith pegged exchange rates before $\therefore$ 1973, $\mathrm{Y}(\mathrm{I}, \mathrm{GB})$ can be well represented by the process 


\section{$1962 I-1972 I V$}

$$
\begin{aligned}
& y(I, G B, t)=\underset{(.002)(.008-.57 y(I, G B, t-1)-.63 y(I, G B, t-2)}{(.16)} \\
& \frac{-.56}{(.15)} \mathrm{y}(I, G B, t-3)+\underset{(.17)}{.36} \mathrm{y}(I, G B, t-4)+e(t)-\frac{.30}{(.20)}(t-4) \\
& \operatorname{adj} \cdot R^{2}=.84 \quad D W=2.01 \quad s e=.034 \text {, }
\end{aligned}
$$

while estimation of the same equation from 1973 through 1985 yields

\section{I-1985IV}

$$
\begin{aligned}
& y(I, G B, t)= .008-.51 y(I, G B, t-1)-.43 y(I, G B, t-2) \\
&(.002)(.10) \quad(.11) \\
&- .45 y(I, G B, t-3)+.59 y(I, G B, t-4)+e(t)-.91 e(t-4) \\
&(.11)(.11) \\
& \text { adj } R^{2}=.84 \quad D H=1.96 \quad s e=.034,
\end{aligned}
$$

and estimation for the period 1979 I-1985IV, during vhich the bilateral exchange rate floated, yields

\section{$1979 I-1985 I \mathrm{~V}$}

$$
\begin{aligned}
& y(I, G B, t)=\frac{.010-.33 y(I, G B, t-1)-.23 y(I, G B, t-2)}{(.006)(.13)} \\
& \frac{-.25}{(.13)} \mathrm{y}(I, G B, t-3)+.75 y(I, G B, t-4)+e(t)-.86 e(t-4) \\
& \text { adj } \cdot R^{2}=.86 \quad D H=1.65 \quad s e=.030 \text {. }
\end{aligned}
$$

or, including another autoregressive term, 
$1979 \pm-1985 \mathrm{IV}$

$$
\begin{aligned}
& y(I, G B, t)=\frac{.010-(.21 y(I, G B, t-1)-.04 y(I, G B, t-2)}{(.012)(.11)}
\end{aligned}
$$

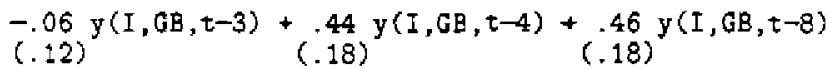

$$
\begin{aligned}
& +e(t)-.88 e(t-4) \\
& \text { (.28) } \\
& \operatorname{adj} \cdot R^{2}=.89 \quad \mathrm{DH}=1.90 \quad \mathrm{se}=.027 \text {. }
\end{aligned}
$$

There is substantial evidence of a break in the statistical process describing the relative output growth rate in Ireland and Great Eritain. Figure 12 shows a plot of the $\log$ likelihood assuming that there is a single break in the process, with models of the form (3a) prior to the break and (3c) after the break. The figure provides some evidence that a break in the process occurred about two years before the change in the exchange rate system. The peak of the likelihood function occurs in the fourth quarter of 1976. A test of the hypothesis that a break occurred in $1976 I V$ yeilds an $F$ statistic of 2.931, which exceeds the critical value of the $F$ distribution with 6 and 90 degrees of freedom at the .02 level. Then the relative output growth rate is described by the models

\section{I-1976III}

$$
\begin{aligned}
& y(I, G B, t)= .008-.56 y(I, G B, t-1)-.62 y(I, G B, t-2) \\
&(.002)(.12)(.13) \\
&- .55 y(I, G B, t-3)+.39 y(I, G B, t-4)+e(t)-.57 \mathrm{e}(t-4) \\
&(.13) \quad(.14) \\
& \text { adj } R^{2}=.83 \quad D W=1.98 \quad \text { se }=.036,
\end{aligned}
$$

and 
$1976 \mathrm{IV}-1985 \mathrm{IV}$

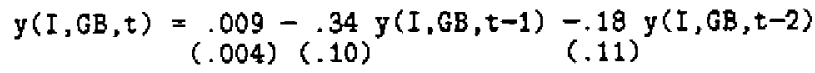

$$
\begin{aligned}
& \frac{-.21}{(.10)} y(I, G B, t-3)+\frac{.42}{(.16)} y(I, G B, t-4)+\frac{.31}{(.16)} y(I, G B, t-8) \\
& +e(t)-.92 e(t-4) \\
& \text { (.24) } \\
& \text { adj. } R^{2}=.91 \quad D W=1.65 \quad \text { sem. } 026 \text {. }
\end{aligned}
$$

The estimated residuals from equations ( $4 a$ ) and (4b) shou no signs of autocorrelation or heteroscedasticity, and the equations show no signs of parameter instability then estimated recursively. Dne interpretation of these results is that some changes occurred around 1976 that altered the real economic connections between Ireland and Britain, that these changes show up as a break in the statistical process describing relative output grouth in the two countries, and that these changes contributed to the decision by Ireland to abandon the pegged exchange rate with Great Britain.

\section{Canada}

The Canadian float from 1951 to 1962 provides another "experiment" uith floating exchange rates aside from the post-1973 float. Stockmar (1983) and. Mussa (1986) have used this episode to help distinguish the changes in real exchange rate variability that coincide with a change in the exchange rate system from the effects of other disturbances around and after 1973. The Canadian dollar resumed its float against the US dollar in the first quarter of 1970. If models in which the exchange rate system plays an important rale are correct, we should expect to find changes in the behavior of trade and macroeconomic variables in Canada at both of these dates. The change in the Canadian trade balance (in Canadian dollars) is shoun in Figure 13, and the 
charige divided by the level of Canadian exports is shown in Figure 14. There is little evidence of changes in the variability of the trade balance at times vhen the exchange rate system changed. While the periods frior to 1962 and after 1970 may be characterized by a different variance of the change in the trade balance, the relation is not monotonic. This is, there is no evidence of similarity between the first and second floating-rate periods in this series. There is little evidence to support the hypothes is that changes over time in the variability of the trade balarce are due to changes in the exchange rate system.

These two case studies reinforce the results from the earlier sections. The volatility of the real exchange rate is higher under flexible rates than under fixed rates, as the Irish case clearly shous. But the behavior of real aggregates such as industrial production and trade flovs do not appear to change as a result of a change in the exchange rate system.

\section{Conclusions}

There is evidence that business cycles have become more nation-apecific and less vorlduide since 1973. Real exchange rates have become more volatile. Some other series, such as some trade series and industrial production, have also become more volatile in the latter period, though the magnitude of the increase is much smaller. Heal government consumption spending has become more highly correlated across countries. But - aside from real exchange rates - there is little indication that these changes are related to the choice of exchange rate system. Evidence from the Irish and Canadian episodes suggest little connection betveen the exchange rate system and changes in the stochastic properties of econonic aggregates. A large class of theoretical models implies that the exchange rate system has 
important effects on a number of macroeconomic quantities; hovever, we have found little evidence of quantities for which the exchange rate system is an important determinant. 


\section{References}

Baxter, Marianne. (1988) "Business Cycles, Stylized Facts, and the Exchange Rate Regime: Evidence from the United States," vorking paper, Detober 1988 .

Burns, Arthur and Wesley C. Mitchell. (1941) Measuring Business Cycles, Net York, National Bureau of Economic Research.

Darby, Michael R. and James R. Lothian. (1988) "International Transmission Afloat," forthcoming, NBER Conference Volume in Honor of Anna $J$. Schwartz.

Engle, Robert. (1974) "Band Spectrum Regression," International Economie Review 15, 1-11.

Fansen, Gary. (1985) "Indivisible Labor and the Busiress Cycle,"Journal of Monetary Economies 16, 309-27.

Hodrick, Robert and Edvard Prescott. (1980) "Post-was U.S. Business Cycles: An Empirical Investigation," vorking paper, Carnegie-Mellon University.

King, Robert, Charles Plosser, and Sergio Rebelo. (1987) "Grouth, Production, and Business Cycles," manuscript, University of Rochester.

King, Robert, Charles Plosser, James Stock, and Mark Watson. (1987) "Stochastic Trends and Economic Fluctuations," Rochester Center for Economic Research Horking Paper $\$ 79$. 
Kydland, Fins and Eduard Prescott. (1982) "Time to Build and Aggregate Fluctuations," Econometrica 50, 1345-70.

Long. John and Charles Plosser. (1983) "Real Business Cycles," Journal of Polizical Economy $91,1345-70$.

Lucas. Robert E., Jr. (1981) "Understanding Business Cycles," CarnegieRochester Conference Series on Public Policy 5, (1977), 7-29, Reprinted in Studies in Business Cycle Theory, Cambridge Mass., MIT Press, 213-39.

Mitchell, Hesiey C. (1927) Business Cycles: The Problen and Its Setting, Nev York, National Bureau of Economic Research.

- (1951) What Happens During Business Cycles, Nev York, National Bureau of Economic Research.

Morgenstern, Dskar (1959) International Financial Transactions and Business Cycles, New York, National Bureau of Economic Research.

Mussa, Michael, (1986) "Nominal Exchange Rate Regimes and the Behavior of Real Exchange Rates," K. Brunner and A.H. Meltzer, eds. , Real Business Cycles, Real Exchange Rates, and Actual Policies, Carnegio-Rochester Conference Series on Public Policy, Autumn.

Nelson, Charles and Charles Plosser (1982) "Trends and Random Walks in Macroeconomic Time Series," Journal of Monetary Economics 10, 139-67. 
Prescott, Edward. (1986) "Theory Ahead of Busiress Cycle Measurement," Carnegie-Rochester Conference Series on Public Policy 25, $11-66$.

Sargent, Thomas, (1979) Macroecopomic Theory, Academic Press.

Stock, James and Mark Watson. (1987) "Testing for Common Trends," Hoover Institution Discussion Paper \#E-87-2.

Stockman, Alan. (1983), Real Exchange Rates under Alternative Nominal Exchange Rate System, Journal of International Money and Finance 2 , 147-166. 


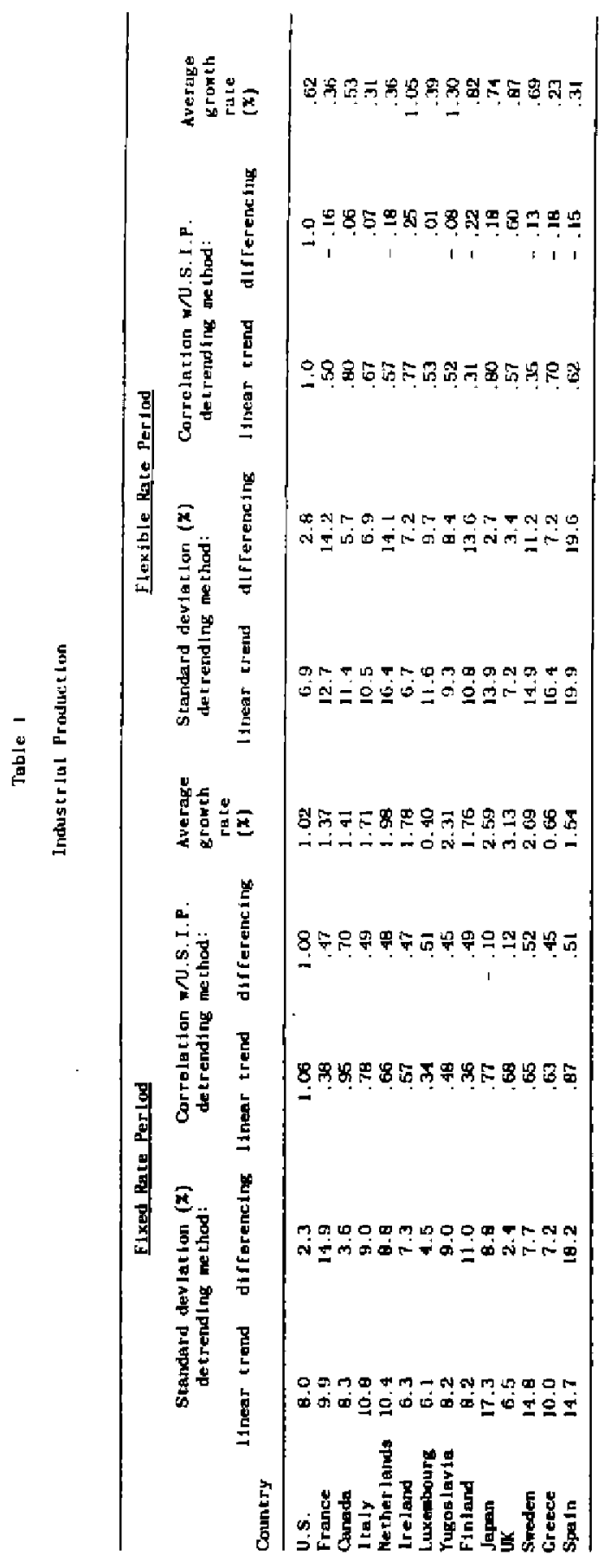


Table 2

Consumption: 12 OECD countries

single linear separate linear log differences trend trends

\section{fixed flexible fixed flexible fixed flexible}

\begin{tabular}{lcccccccc} 
Country & $\sigma$ & $\sigma$ & $\sigma$ & $\sigma$ & $\mu$ & $\sigma$ & 12 & $\sigma$ \\
\hline Germany & 3.5 & 4.6 & 2.2 & 2.9 & 1.2 & 1.2 & 0.4 & 1.0 \\
France & 3.0 & 4.8 & 1.5 & 2.1 & 1.4 & 1.7 & 0.7 & 0.8 \\
Australia & 0.5 & 2.0 & 0.1 & 1.0 & 1.2 & 0.2 & 0.7 & 0.9 \\
Canada & 2.1 & 17.1 & 1.5 & 15.8 & 1.1 & 1.1 & 2.4 & 11.5 \\
I taly & 0.9 & 2.5 & 0.5 & 2.3 & 1.1 & 0.9 & 0.6 & 1.1 \\
Netherlands & 4.9 & 12.7 & 4.7 & 8.5 & 3.0 & 7.6 & 1.7 & 4.5 \\
Finland & 4.9 & 3.8 & 3.6 & 3.2 & 4.2 & 8.1 & 0.5 & 4.4 \\
japan & 6.9 & 5.3 & 0.9 & 1.8 & 2.1 & 1.0 & 0.8 & 1.3 \\
Switzerland & 3.8 & 3.4 & 1.1 & 1.8 & 1.2 & 1.5 & 0.3 & 1.4 \\
U. K. & 1.6 & 3.2 & 1.3 & 2.7 & 0.6 & 1.1 & 0.5 & 1.4 \\
Sweden & 7.1 & 7.0 & 6.2 & 5.6 & 1.3 & 1.2 & 0.4 & $\mathbf{8 . 8}$ \\
Austria & 10.9 & 8.5 & 0.4 & 8.5 & 9.5 & 0.7 & 0.7 & 14.0 \\
\hline
\end{tabular}




\begin{tabular}{|c|c|c|c|c|c|c|c|c|}
\hline r & 管曷 & 8 & 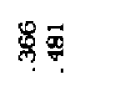 & 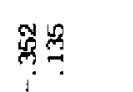 & 覃 & $\vec{z}$ & 㐁武 & 象 \\
\hline . & 号畐 & 捅 & $\underset{7}{\sim}$ & 象蛋 & 疍 & 菓昌 & 象象 & 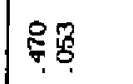 \\
\hline$\infty$ & 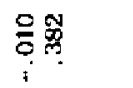 & 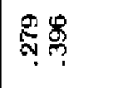 & 哥吕 & 敬需 & 唡器 & 鱼总 & $\stackrel{\infty}{0}$ & 眊是 \\
\hline$\sigma$ & $8 \%$ & 要察 & 葛是 & 위ำ & 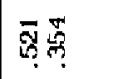 & קृ & $E_{0}^{\infty}$ & 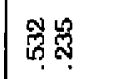 \\
\hline$\Rightarrow$ & ชุด & 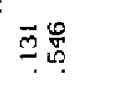 & $\overline{0} 8$ & 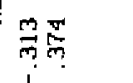 & $\overline{5}$ & 虽总 & 웜류 & 总罥 \\
\hline$\infty$ & จุํำ & 果品 & 웅물 & की & 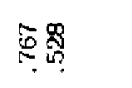 & 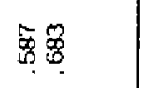 & 象突 & 뚜ำ \\
\hline - & $\begin{array}{l}\infty \\
0.8 \\
0\end{array}$ & 78 & 80 & 충 & 盖舫 & $g x$ & $\stackrel{90}{0}$ & : \\
\hline 。 & 果柿 & 亦雷 & 悉要 & . & 果商 & 芯占 & 8 & F \\
\hline$\vec{\imath}$ & 影兽 & 웍 & 舜莡 & 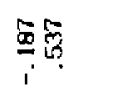 & 蛋 & 患总 & $\underset{8}{80}$ & 8 \\
\hline N & 野 & 员草 & $\tilde{\alpha} \frac{\pi}{x}$ & 㽟 & 的哭 & 88 & : & 8 \\
\hline $\overrightarrow{1}$ & 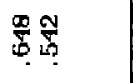 & 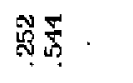 & 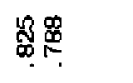 & 80 & $\overrightarrow{8}$ & 覃是 & 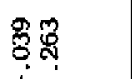 & 象早 \\
\hline$T$ & 落葛 & 8 & 88 & 点 & 8 & 事量 & 욕목 & $\stackrel{0}{2}$ \\
\hline$\varphi$ & 㝵 & $E \stackrel{9}{7}$ & ? & 里曷 & 尊曷 & 骂 & 可哭 & 역 \\
\hline$i$ & 栾亭 & 奇昂 & 象宽 & 5. & \&్ู & $\overrightarrow{8}$ & 釆思 & $\stackrel{\square}{\underline{m}}$ \\
\hline T & 8 웅준 & 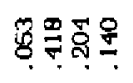 & 8 & 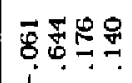 & 측 & 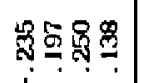 & № & 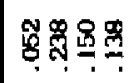 \\
\hline 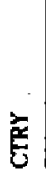 & 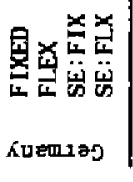 & 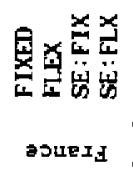 & 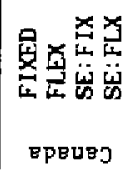 & 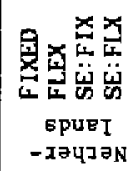 & 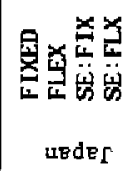 & 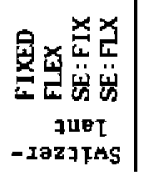 & 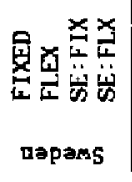 & 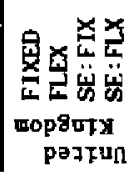 \\
\hline
\end{tabular}




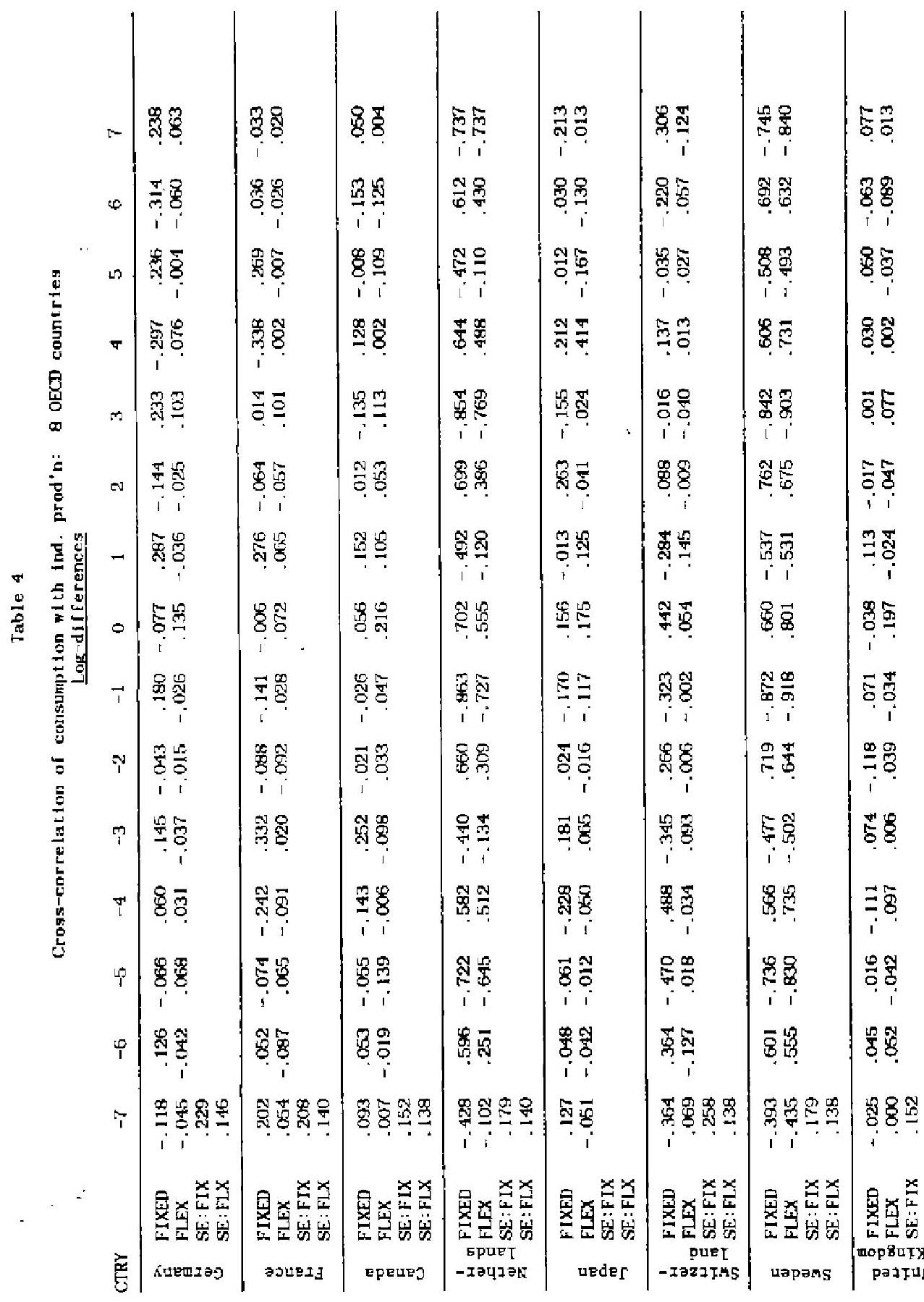


TABLE 5

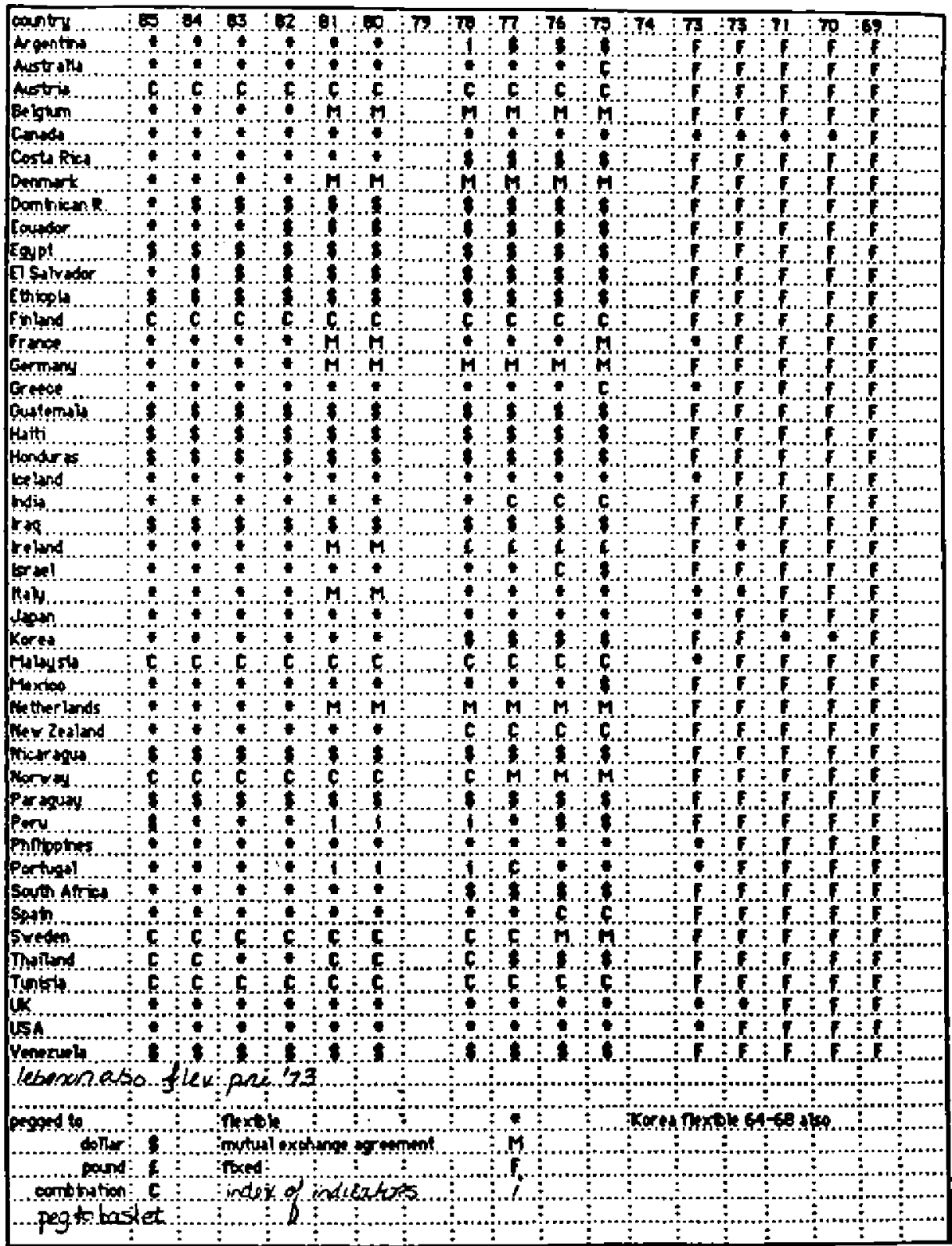


Table 6

Growth Rates of Real Exports and Imports

\begin{tabular}{|c|c|c|c|c|c|c|c|c|}
\hline \multirow[b]{2}{*}{ Country } & \multicolumn{4}{|c|}{ Exports } & \multicolumn{4}{|c|}{ Imports } \\
\hline & $\begin{array}{r}F \\
\mu(x)\end{array}$ & ked $\sigma(\mathbf{x})$ & $\begin{array}{c}\text { Flex } \\
\mu(\boldsymbol{x})\end{array}$ & $\begin{array}{l}\text { Able } \\
\sigma(x)\end{array}$ & $\mu(\mathbf{X})$ & $\operatorname{xed}(\mathrm{x})$ & $\underset{\mu(\boldsymbol{X})}{\text { Fle }}$ & $\begin{array}{r}\text { xible } \\
\sigma(\mathbf{x})\end{array}$ \\
\hline Germany & 2.0 & 3.6 & 0.5 & 5.2 & 2.0 & 3.5 & 0.6 & 4.9 \\
\hline France & 1.6 & 6.5 & 0.5 & 4.5 & 1.9 & 5.0 & 0.6 & 4.9 \\
\hline Denmark & 1.4 & 3.4 & 0.6 & 5.6 & 1.5 & 4.7 & 0.2 & 6.3 \\
\hline Australia & 1.2 & 7.7 & 1.1 & 5.7 & 1.1 & 9.4 & 1.8 & 7.4 \\
\hline Canada & 1.7 & 4.3 & 0.7 & 3.8 & 1.1 & 3.9 & 0.7 & 4.7 \\
\hline Italy & 2.5 & 3.5 & 1.1 & 7.0 & 2.2 & 5.3 & 0.9 & 8.5 \\
\hline Ne ther lands & 2.1 & 3.3 & 0.6 & 5.7 & -- & --- & - & - \\
\hline New Zealand & 4.3 & 28.6 & 1.7 & 10.6 & 4.9 & 26.7 & 2.7 & 9.9 \\
\hline Iceland & 1.9 & 14.2 & 0.3 & 13.9 & -0.2 & 18.2 & 0.2 & 10.7 \\
\hline Ireland & 1.8 & 6.1 & 1.5 & 5.8 & 1.8 & .6 .0 & 1.0 & 7.1 \\
\hline Finland & 1.7 & 9.7 & 1.0 & 8.1 & 1.8 & 9.4 & 0.7 & 8.6 \\
\hline Greece & 2.0 & 12.0 & I. 2 & 18.1 & 2.0 & 9.1 & 0.8 & 24.8 \\
\hline Japan & 3.2 & 3.3 & 1.6 & 5.3 & 2.8 & 4.3 & 0.7 & 5.7 \\
\hline Swi tzer land & 1.9 & 1.8 & 5.9 & 2.2 & 2.2 & 3.1 & 0.5 & 6.4 \\
\hline Spain & 2.4 & 10.5 & 1.4 & 8.8 & 4.0 & 8.3 & 0.5 & 8.0 \\
\hline Tuskey & 3.1 & 21.6 & 2.0 & 17.8 & 3.3 & 15.1 & 1.9 & 15.3 \\
\hline Por tugal & 2.2 & 8.1 & 0.3 & 9.7 & 2.0 & 11.6 & 0.0 & 13.3 \\
\hline LKK & 0.8 & 5,1 & 0.7 & 6.2 & 0.7 & 3.3 & 0.5 & 5.3 \\
\hline Sweden & 1.7 & 3.9 & 0.2 & 8.6 & 1.5 & 3.9 & 0.2 & 6.4 \\
\hline S. Africa & 0.2 & 7.2 & 1.6 & B. 4 & 1.1 & 7.6 & 1.0 & 9.3 \\
\hline Costa Rica & 1.1 & 35.7 & 1.4 & 22.2 & 2.2 & 15,0 & 0.0 & 11.9 \\
\hline Dom, Rep. & 0.2 & 26.4 & 0.6 & 39.1 & 1.5 & 23.2 & 1.5 & 18.4 \\
\hline El Salvador & 8.6 & 79.7 & -2.2 & 117.3 & 1.1 & 9.0 & -3.1 & 117.5 \\
\hline Gua temala & 0.7 & 50.5 & 0.0 & 28.7 & 1.2 & 11.0 & -0.6 & 14.5 \\
\hline Haíti & -0.7 & 38.4 & 0.6 & 24.6 & 0.8 & 17.4 & 2.6 & 12.6 \\
\hline Honduras & 1.3 & 28.4 & -14.8 & 80.1 & 1.6 & 10.9 & -17.4 & 115.0 \\
\hline Mexico & 0.2 & 15.7 & 3.6 & 15.3 & 0.6 & 7.3 & 1.7 & 15.3 \\
\hline Paraguay & 2.2 & 39.5 & 0.0 & 62.9 & 2.5 & 19.7 & 2.1 & 28.2 \\
\hline Peru & 1.2 & 14.0 & 1.8 & 18.0 & 0.0 & 10.5 & 0.5 & 17.6 \\
\hline Venezuela & 0.4 & 8.7 & 1.1 & 18.3 & 0.6 & 16.8 & 0.8 & 12.9 \\
\hline Egypt & 0.0 & 44.4 & 0.6 & 42.8 & 0.4 & 10.0 & 2.2 & 48.3 \\
\hline India & 0.4 & 12.5 & 0.7 & 14.7 & -0.4 & 14.0 & 2.7 & 16.9 \\
\hline Korea & 11.9 & 10.2 & 3.9 & 14.0 & 12.9 & 14.5 & 3.4 & 12.5 \\
\hline Malaysia & 0.9 & 7.7 & 2.4 & 8.0 & 1.1 & 5.5 & 2.0 & 7.7 \\
\hline Philippines & 2.5 & 15.9 & 0.7 & 13.0 & 2.1 & 13.9 & 0.4 & 11.4 \\
\hline Thai land & 0.6 & 16.4 & $=4.0$ & 179.3 & 2.0 & 4.3 & 3.1 & 6.2 \\
\hline Ethlopia & -4.0 & 46.1 & -0.6 & 37.1 & -0.6 & 12.3 & 0.7 & 24.7 \\
\hline Libera & 0.2 & 9.4 & -1.2 & 13.6 & 0.6 & 14.6 & $=1.0$ & 16.1 \\
\hline Somal ia & -0.7 & 25.4 & 3.1 & 65.3 & -1.3 & 17.2 & -4.4 & 49.0 \\
\hline Tunisia & 0.8 & 16.7 & 2.6 & 27.2 & 2.0 & 16.5 & 2.4 & 16.7 \\
\hline Israel & - & $-\infty$ & --- & --- & 1.3 & 23.2 & 4.9 & 50.3 \\
\hline
\end{tabular}


Table 7

Tests for Change in Volatility of Exports and Imports from pre-1970 to post-1973

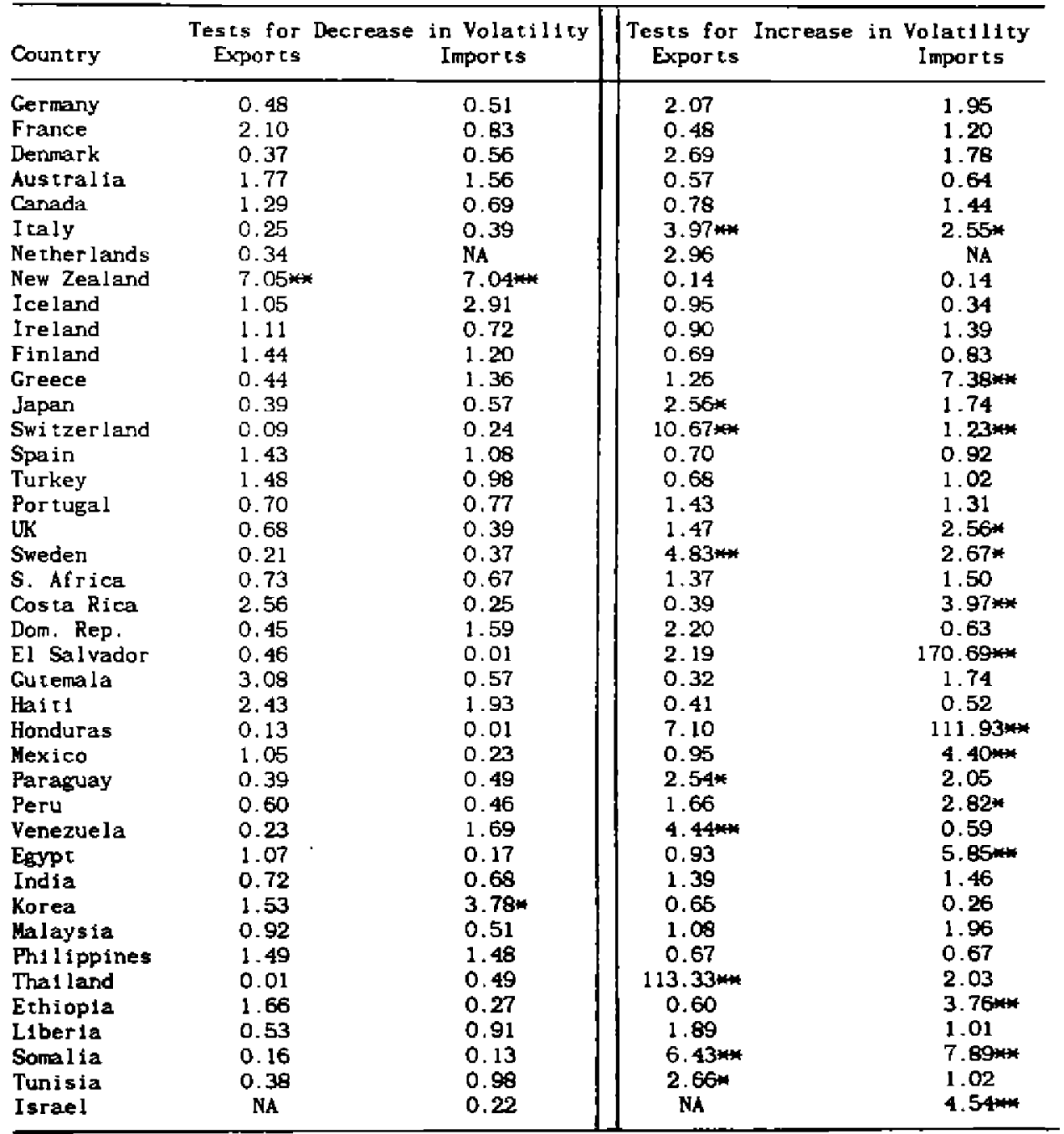

* Significant at 57 level

* Significant at 17 level 
Table 8

F-tests for Differences in Mean Growth Rates of Exports and Imports

Test Statistics:

\begin{tabular}{|c|c|c|}
\hline Country & Exports & Imports \\
\hline Germany & 1.57 & 1.54 \\
\hline France & 0.95 & 1.17 \\
\hline Dennark & 0.81 & 1.10 \\
\hline Australia & 0.06 & -0.32 \\
\hline Canada & 1.18 & 0.44 \\
\hline I taly & 1.18 & 0.86 \\
\hline Nether lands & 1.50 & NA \\
\hline New Zealand & 0.44 & 0.40 \\
\hline Iceland & 0.54 & -0.13 \\
\hline Ireland & 0.24 & 0.58 \\
\hline Finland & 0.37 & 0.58 \\
\hline Greece & 0.24 & 0.30 \\
\hline Japan & $1.70 *$ & $1.95 x$ \\
\hline Switzerland & 1.38 & i. .57 \\
\hline Spain & 0.49 & 2.03 \\
\hline Turkey & 0.26 & 0.44 \\
\hline Por tugal & 1.00 & 0.76 \\
\hline UK & 0.08 & 0.21 \\
\hline Sweden & 1.04 & 1.15 \\
\hline S. Africa & -0.91 & 0.06 \\
\hline Costa Rica & -0.05 & 1.18 \\
\hline Dom. Rep. & -0.06 & 0.00 \\
\hline El Salvador & 0.56 & 0.26 \\
\hline Guatema la & 0.09 & 0.72 \\
\hline Halt 1 & -0.21 & -0.48 \\
\hline Honduras & 1.28 & 0.21 \\
\hline Mexico & -1.12 & -0.47 \\
\hline Paraguay & 0.22 & -0.02 \\
\hline Рeтu & -0.19 & -0.18 \\
\hline Venezuela & -0.25 & -0.07 \\
\hline$E_{g y p t}$ & -0.07 & -0.34 \\
\hline India & -0.11 & -1.02 \\
\hline Korea & 0.96 & 1.25 \\
\hline Malaysia & -0.98 & -0.69 \\
\hline Philippines & 0.63 & 0.68 \\
\hline Thei land & 0.12 & -0.72 \\
\hline Ethiopia & -0.31 & -0.21 \\
\hline Liberia & 0.37 & 0.34 \\
\hline Soma lia & -0.29 & 0.32 \\
\hline Tunisia & -0.41 & -0.12 \\
\hline Israel & $N A$ & $=0.35$ \\
\hline
\end{tabular}


Table 9

F-tests for Change in Real Exhange Rate Volatility

( $\log -d 1 \mathrm{fferenced}$ real exchange rate data)

pre-70:4 vs post $-73: 3$

Country

Decrease

Increase

Germany

France

Denmark

Australia

Canada

Italy

Ne ther lands

New Zealand

Iceland

Ireland

Yugos lavia

Finland

Belgium

Greece

Japan

Swi tzer land

Spain

Turkey

Por tugal

UK

Sweden

Austria

S. Africa

Costa Rica

Dom, Rep.

Ecuador

El Salvador

Guatemala

Hait i

Honduras

Mexico

Paraguay

Peru

Venezue1a

Israel

Egypt

India

Korea

Malaysia

Phi lippines

Liberia

Somalia
0.05

0.12

0.09

0.03

0.33

0.03

0.07

0.39

2. 27

0.21

2. $42 \%$

1.01

0.01

0.04

0.03

0.01

0.26

0.64

0.08

0.21

0.03

0. 28

0.01

0.02

0.03

0.48

0.42

0.30

1.28

1.28

0.02

0.06

0.40

0.31

0.49

0.16

2.68*

0.32

0.12

2.86*

3.20*

0.07
$21.16 *$

8. $07 * *$

$10.67 * *$

28. 86*

3. $04 \%$

$35.76 \%$

14. 42**

$22.55 *$

0.44

44.77 \%

0.41

0.99

$88.89 *$

$24.83 k \%$

29.55

78.23

3. $882 \%$

1.55

12. $37 \%$

4.84*

$30.65 * *$

$36.11 * *$

$93.96 *$

$55.46 \times 4$

39. 49 *

2.08

2. 38

3. 34*

0.78

0.78

66.35 *

16. 49 m

2.54*

$3.25 *$

2.02

6. 42**

0.37

3. $12 *$

B. 49

0.35

0.31

12. $84 \%$ 
Table 10

F-test for Change in mean growth rate of real exchange Rate

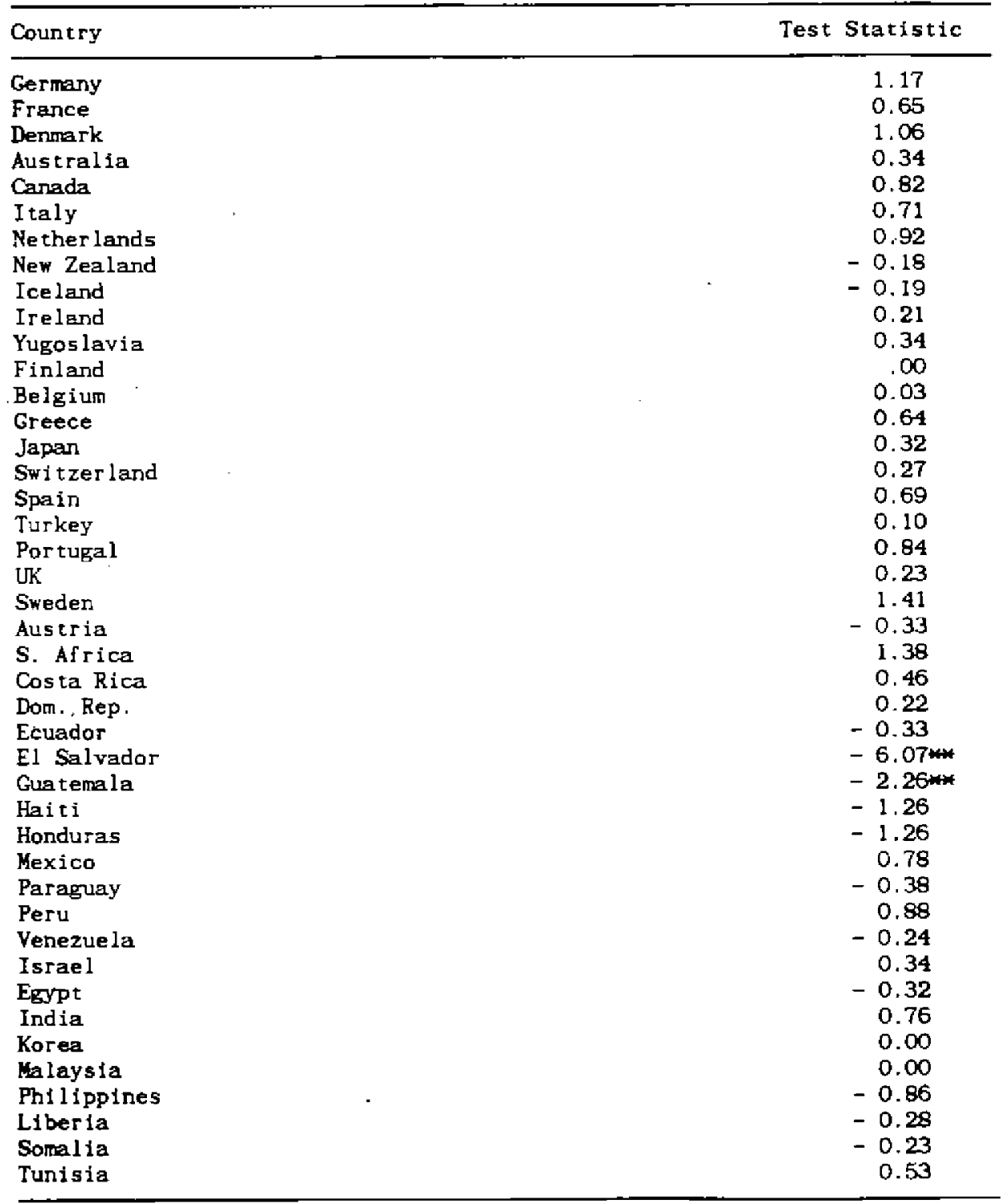

* Significant at $1 \%$ level 
Table 11

Real Exchange Rate Variability

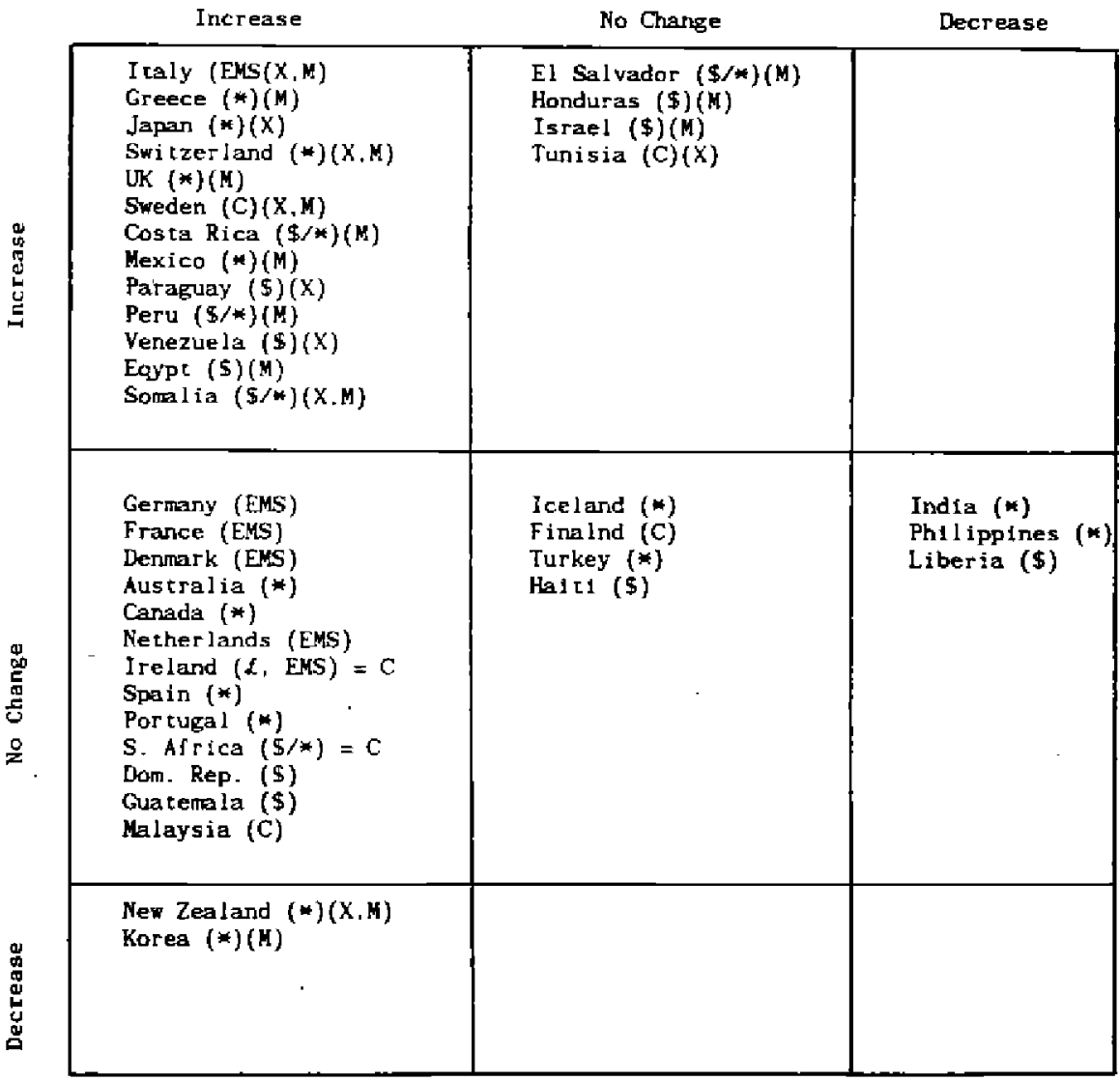

How to read table:

Country Name $\left[\begin{array}{c}\text { exchange rate system } \\ \text { post-73: see Table } \\ 14 \text { for key }\end{array}\right]\left[\begin{array}{l}X: \text { export variabilify changed } \\ M: \text { import variability changed }\end{array}\right]$

e.g.: Hexico (*)(M)

means Mexico was on a floating-rate system after 1973(*), and had a significant change in import variability (H) 
Table 12

Real Exchange Race Variability

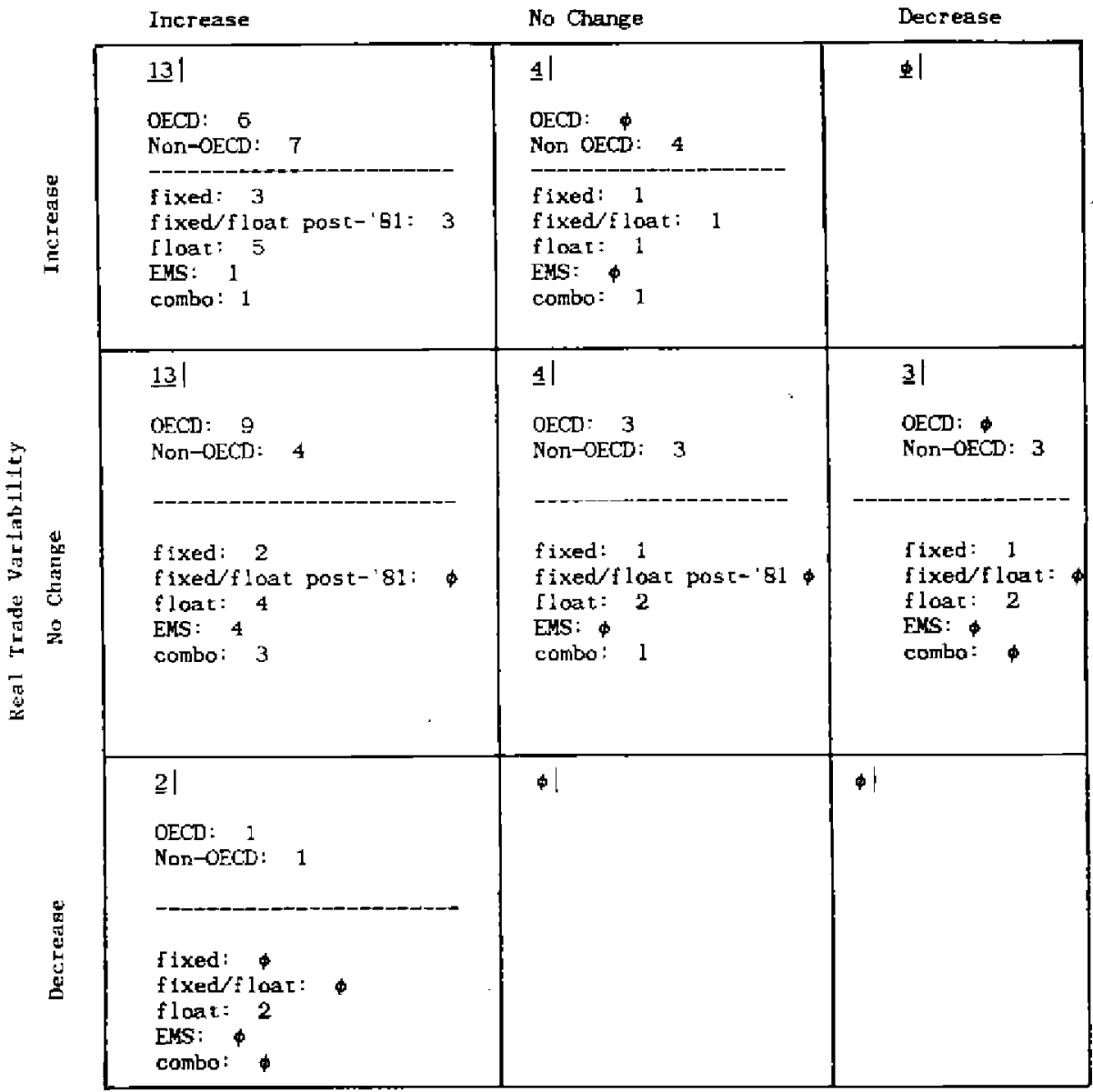

Number in upper-lef corner shows number of countries in the cell (refer to Table 19)

Entries below show breakdown by OECD/non-OECD, and by exchange rate regime 
Table 13

Standard Deviations of Real Government Consumption

Growth Rates - 1960-72 and 1973-85

\begin{tabular}{|c|c|c|c|}
\hline Country & SDPEG & SDFIT & SDDIF \\
\hline Germany & 0.026 & 0.018 & -.008 \\
\hline France & 0.008 & 0.642 & 0.634 \\
\hline Dennark & 0.123 & 0.021 & -.102 \\
\hline Australia & 0.031 & 0.022 & -.009 \\
\hline Canada & 0.031 & 0.016 & -.015 \\
\hline Italy & 0.011 & 0.005 & $=.006$ \\
\hline Ne therlands & 0.017 & 0.016 & -.001 \\
\hline Iceland & 0.023 & 0.026 & 0.003 \\
\hline Ire land & 0.022 & 0.030 & 0.008 \\
\hline Luxembourg & 0.050 & 0.017 & -.033 \\
\hline Finland & 0.004 & 0.010 & 0.006 \\
\hline Belg1um & 0.024 & 0.022 & -.002 \\
\hline Greece & 0.022 & 0.033 & 0.011 \\
\hline Japan & 0.050 & 0.015 & -.035 \\
\hline Switzerland & 0.040 & 0.010 & -.030 \\
\hline Spain & 0.023 & 0.016 & -.007 \\
\hline Turkey & 0.015 & 0.040 & 0.025 \\
\hline Por tugal & 0.053 & 0.040 & -.013 \\
\hline Great Britain & 0.019 & 0.018 & -.001 \\
\hline Norway & 0.031 & 0.014 & -.017 \\
\hline Sweden & 0.021 & 0.012 & -.009 \\
\hline Austria & 0.014 & 0.012 & -.002 \\
\hline
\end{tabular}


Table 14

Average Correlations of Real Government Consumption Growth Rates with Other Countries - 1960-72 and 1973-85

Dos

AVCPEG

AVGFLT

1

0.152

0.321

2

$-.036$

0.106

3

$-.092$

0.224

4

$-.049$

0.275

5

$-.054$

0.171

6

$-.016$

0.343

7

0.101

0.364

8

0.033

0.334

9

$-.087$

0.389

10

0.134

0.425

11

0.131

0.414

12

0.122

0.437

13

$-.073$

0.406

14

o. 134

0.290

15

0.091

$-.098$

16

0.154

0.362

17

$-.019$

0.429

18

0.024

0.312

19

0.122

0.278

20

0.071

0.281 
Table 15

Standard Deviations of Real Exchange Rates of Ireland VS. U.K. or Vs. Germany (various filters)

(percent per quarter)

$60: 1-70: 4$

Ireland vs. UK

levels

differenced

single trend

different trends

Ireland vs. Germany

levels

differenced

single trend

different trends
2.4

.8

2.0

1.1

1. 1

2.6

1. 0

1.0

Table 16

Standard deviation of Ireland's Real Exports and Imports

(percent per quarter)

linear trend removed

real exports

real imports

$\log$-differenced

real exports

real imports

separate trenda renoved
30

31

10

9
29

37

11

9

20

32
35

59

2.6

1.9

2.9

1.1
7.5

3.9

7.6

7.4

\begin{tabular}{lllll} 
real exports & 10 & 20 & 33 & 30 \\
real imports & 14 & 32 & 34 & 49 \\
\hline
\end{tabular}


Table 17

Standard deviation and correlations of industrial production (standard deviations are percent per quarter)

$60: 1-70: 4 \quad 73: 3-78: 4 \quad 79: 1-85: 4 \quad 73: 3-85: 4$

\section{linear trend removed}

$\begin{array}{ccccc}\text { standard deviation: Germany } & 9 & 7 & 7 & 9 \\ \text { standard deviation: Ireland } & 6 & 6 & 7 & 7 \\ \text { standard deviation: U.K. } & 7 & 6 & 7 & 7 \\ \begin{array}{c}\text { Correlation between Ireiand } \\ \text { and U.K. }\end{array} & .48 & .39 & .61 & .59 \\ \begin{array}{c}\text { Correlation between Ireland } \\ \text { and Germany }\end{array} & .75 & .64 & .68 & .70\end{array}$

\section{log-differenced}

$\begin{array}{ccccc}\text { standard deviation: Germany } & 9 & 11 & 8 & 9 \\ \text { standard deviation: Ireland } & 7 & 7 & 7 & 7 \\ \begin{array}{c}\text { standard deviation: U.K. } \\ \begin{array}{c}\text { Corfelation between Ireland } \\ \text { and U.K. }\end{array}\end{array} & 7 & 8 & 7 & 7 \\ \begin{array}{c}\text { Correlation between Ireland } \\ \text { and Germany }\end{array} & .74 & .30 & .36 & .32 \\ \end{array}$




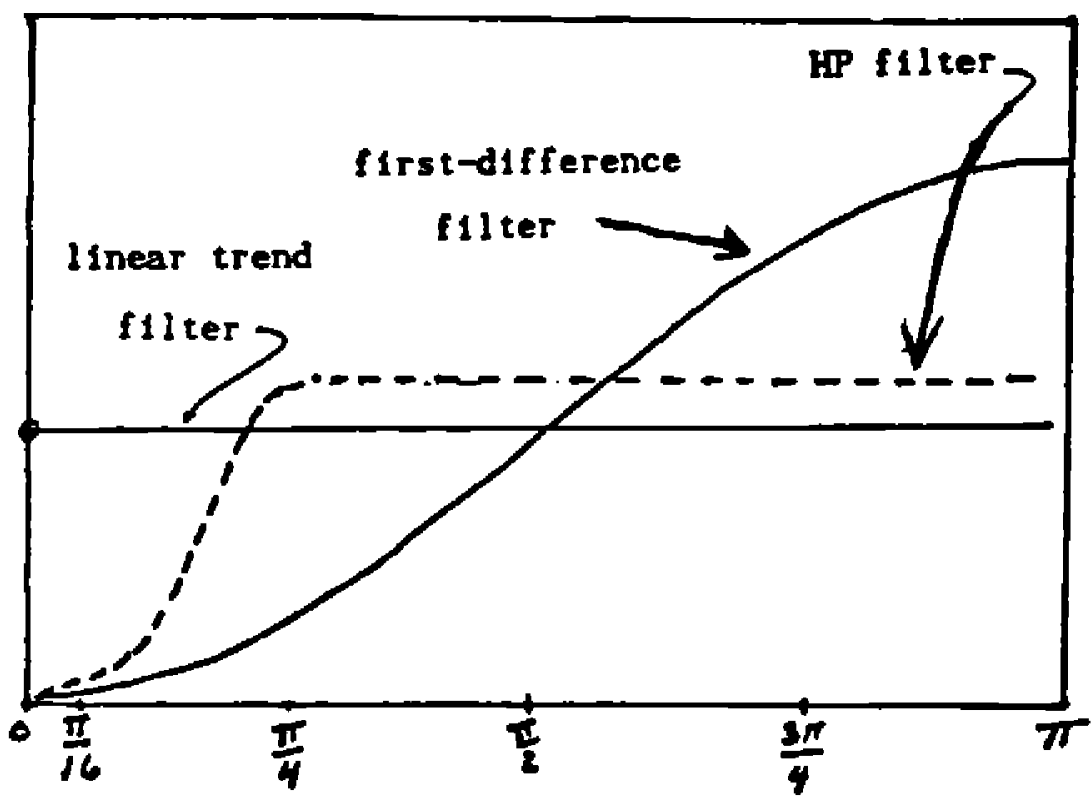

FIGURE 1 


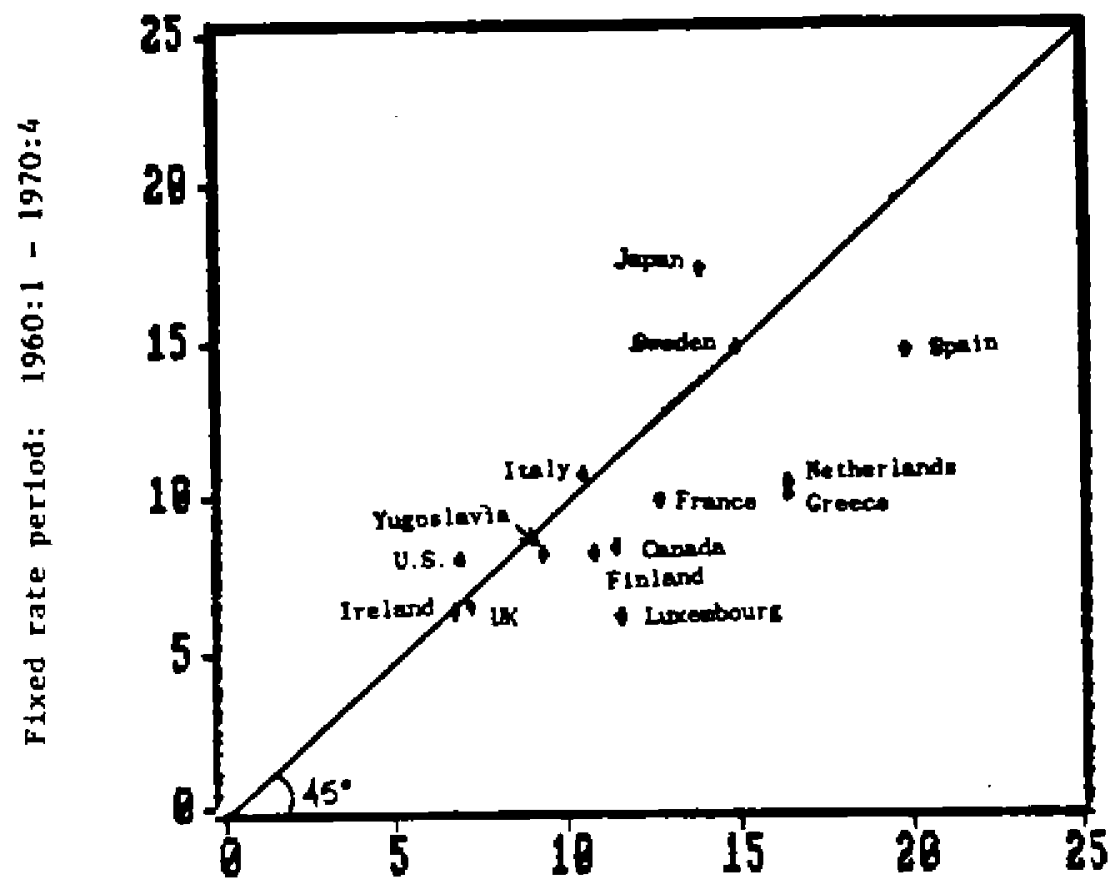

Flexible rate period: 1973:1-1985:4

STANDARD DEVIATION OF LOG INDUSTRIAL PRODUCTION: (\%) LINEAR TREND RENOVED

14 OECD COUNTRIES

FIGLRE 2 


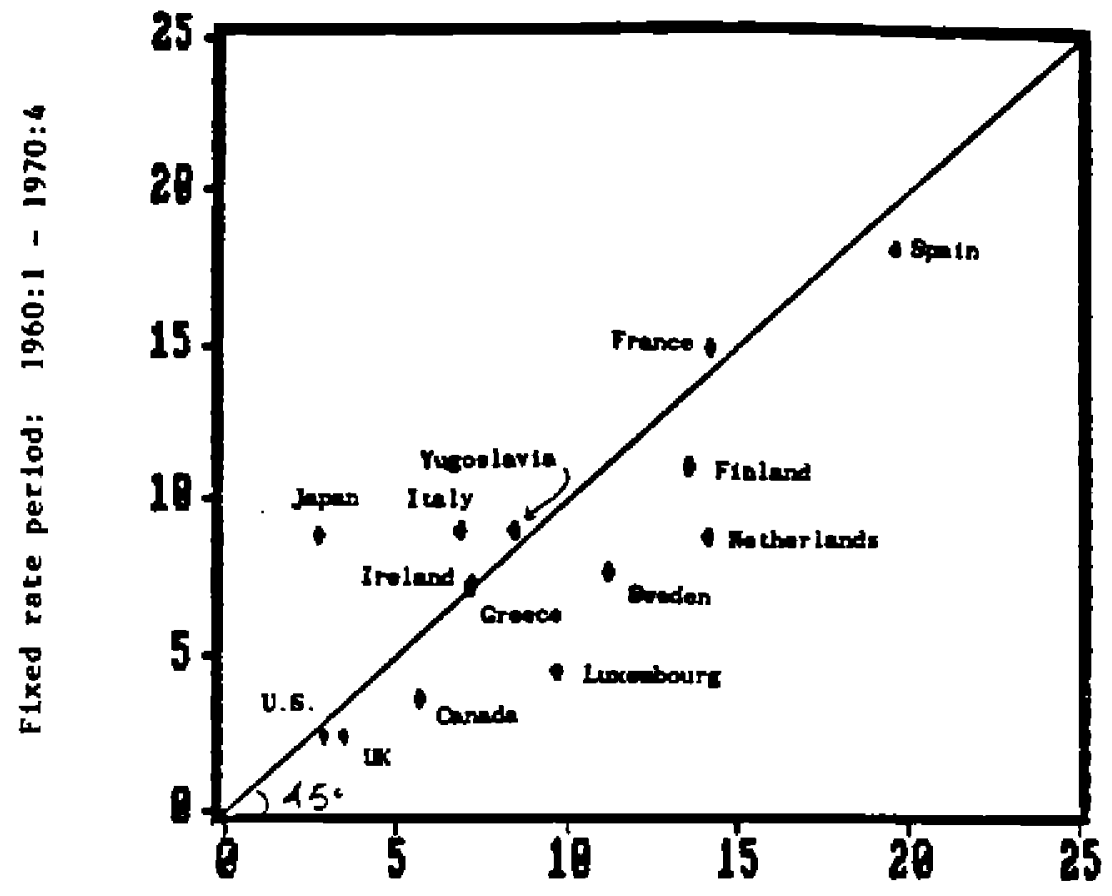

Flexible rate perfod: 1973:1-1985:4

STAVDARD DEVIATION OF QUARTERLY GROHTH RATFS OF

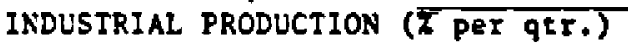

14 OECD COLNTRIES

FIGURF: 3 


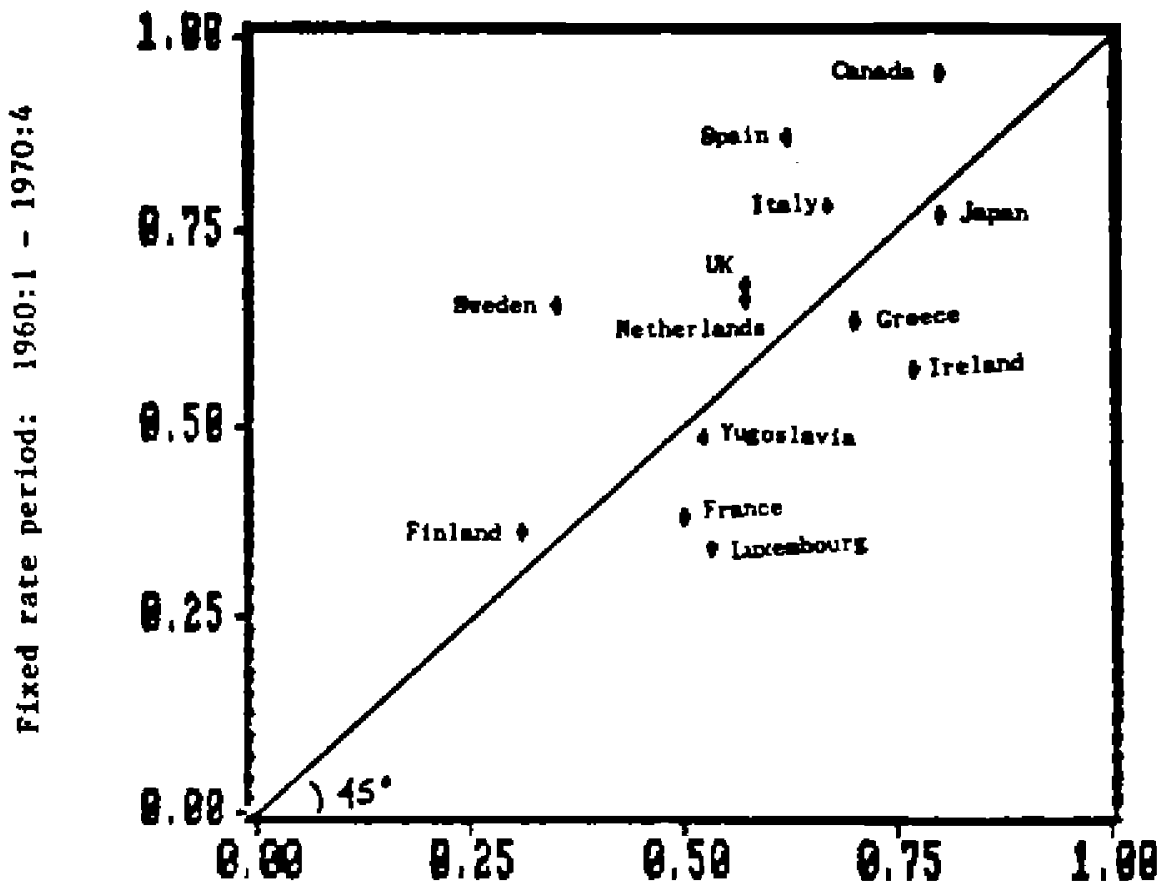

Flexible rate per1od: 1973:1 - 1985:4

CORRELATION OF LOG INDUSTRIAL PRODUCTION WITH LOG OF U.S. INDUSTRIAL PRODUCTION: LINEAR TREND REMOVED.

14 OECD COUNTRIES

FIGURE 4 


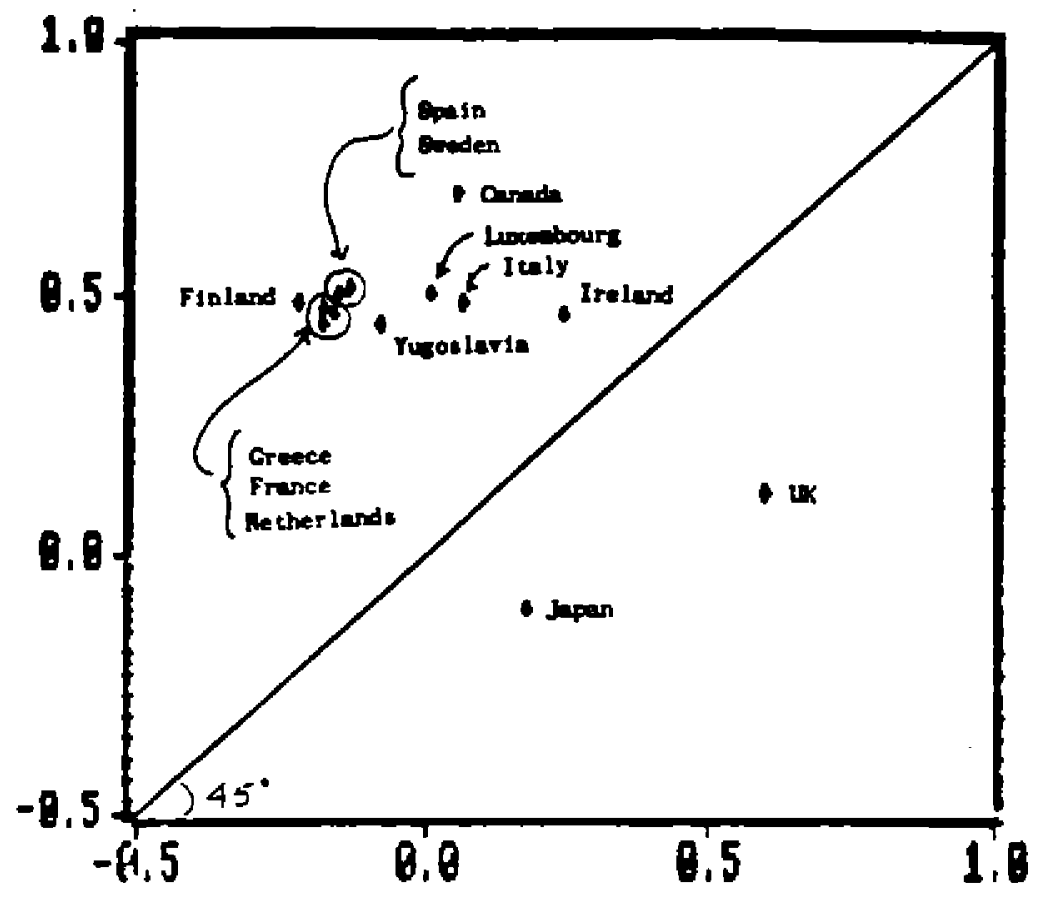

Flexible rate period: 1973:1-1985:4

CORRELATION OF QUARTERLY GROWTH RATES OF INDUSTRIAL

PRODUCTION WITH U.S, GROWTH RATE: 3 OECD COUNTRIES

FIGURE 5 


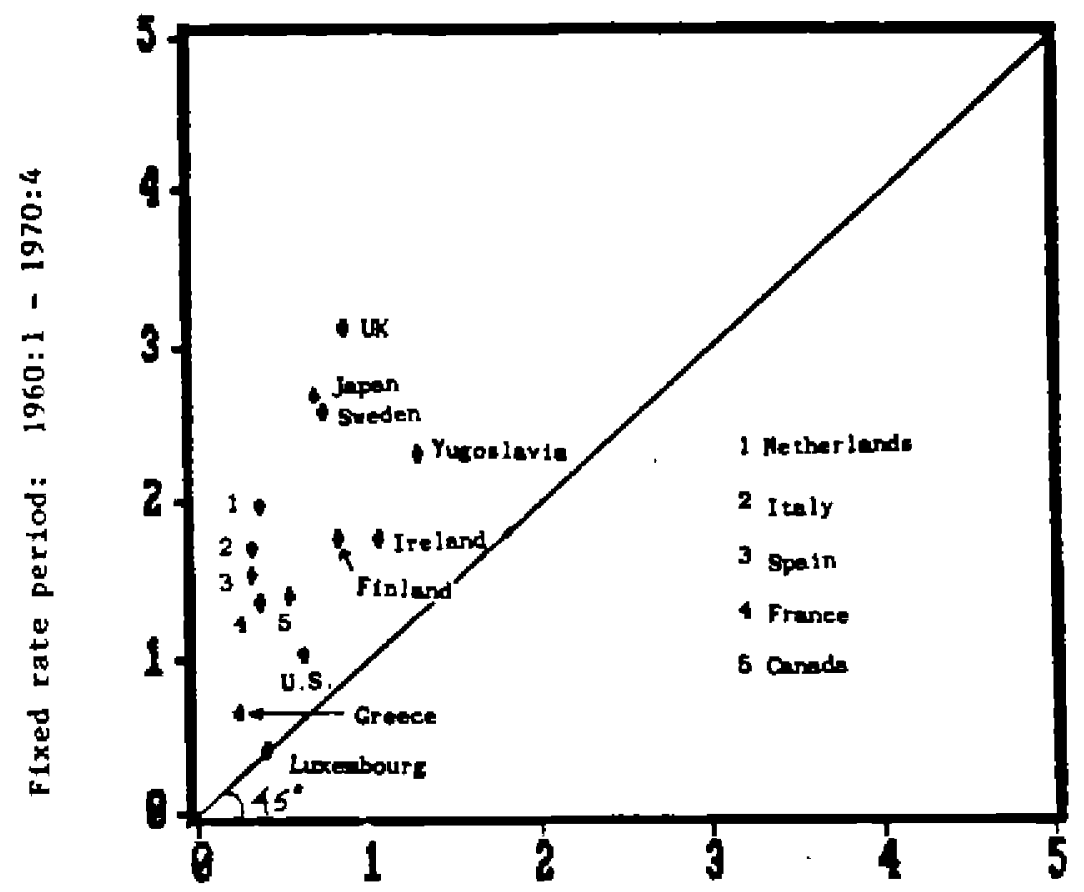

Flexible rate period: 1973:1-1985:4

QUARTERLY GROWTH RATES OF INDUSTRIAL PRODUCTION: I per qtr.

14 OECD COUNTRIES

FIGURE 6 

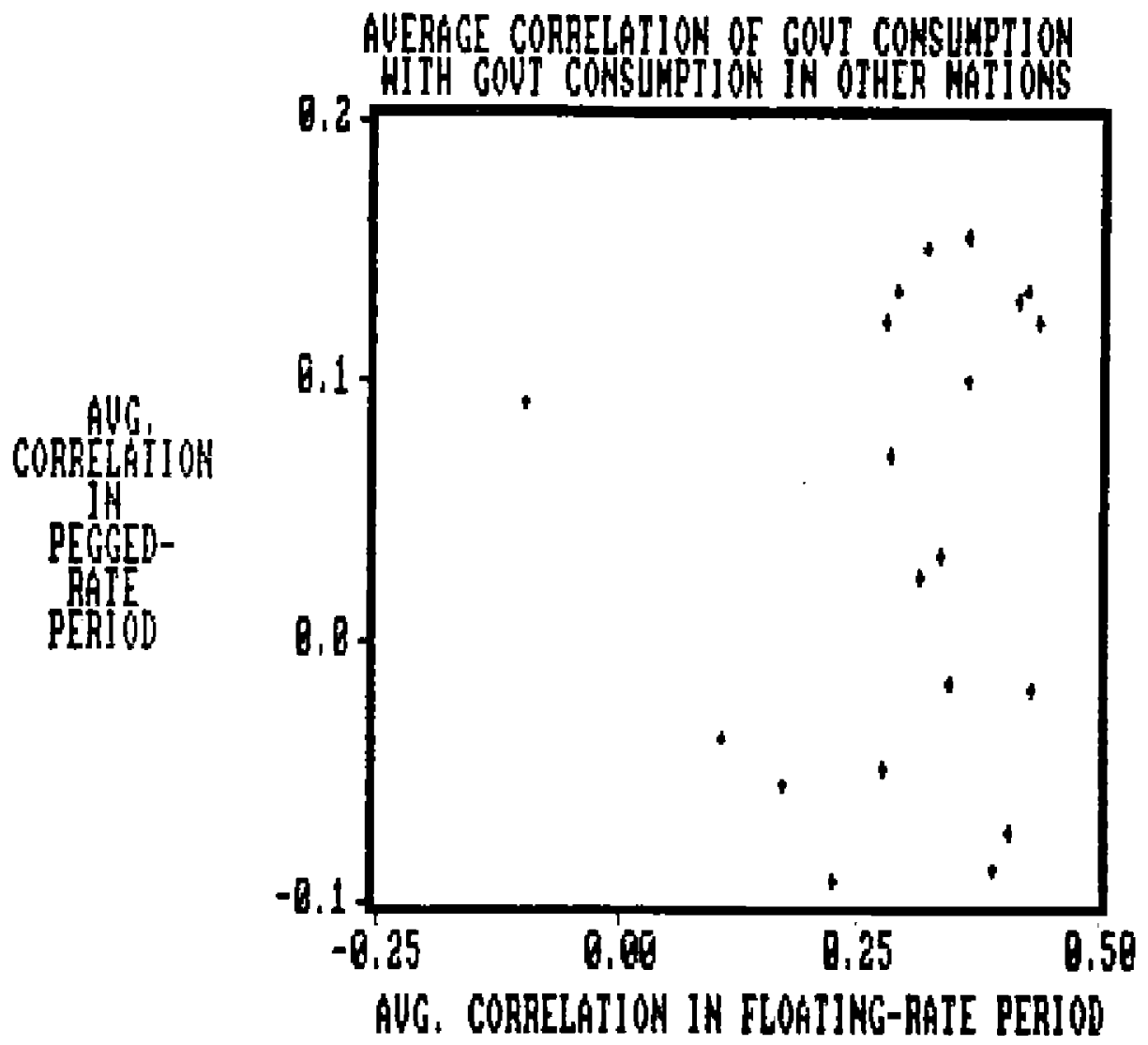

FIGURE 7 

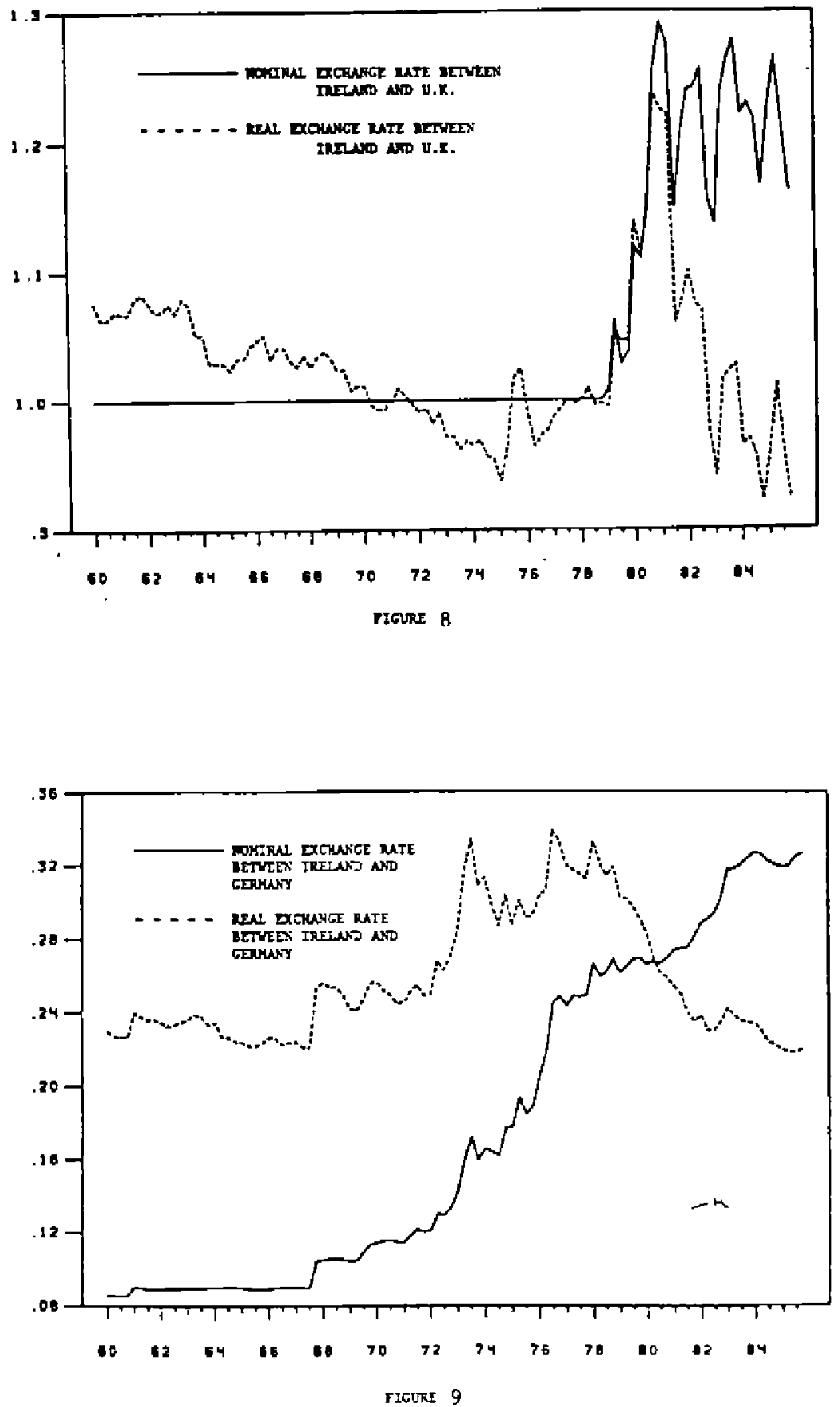


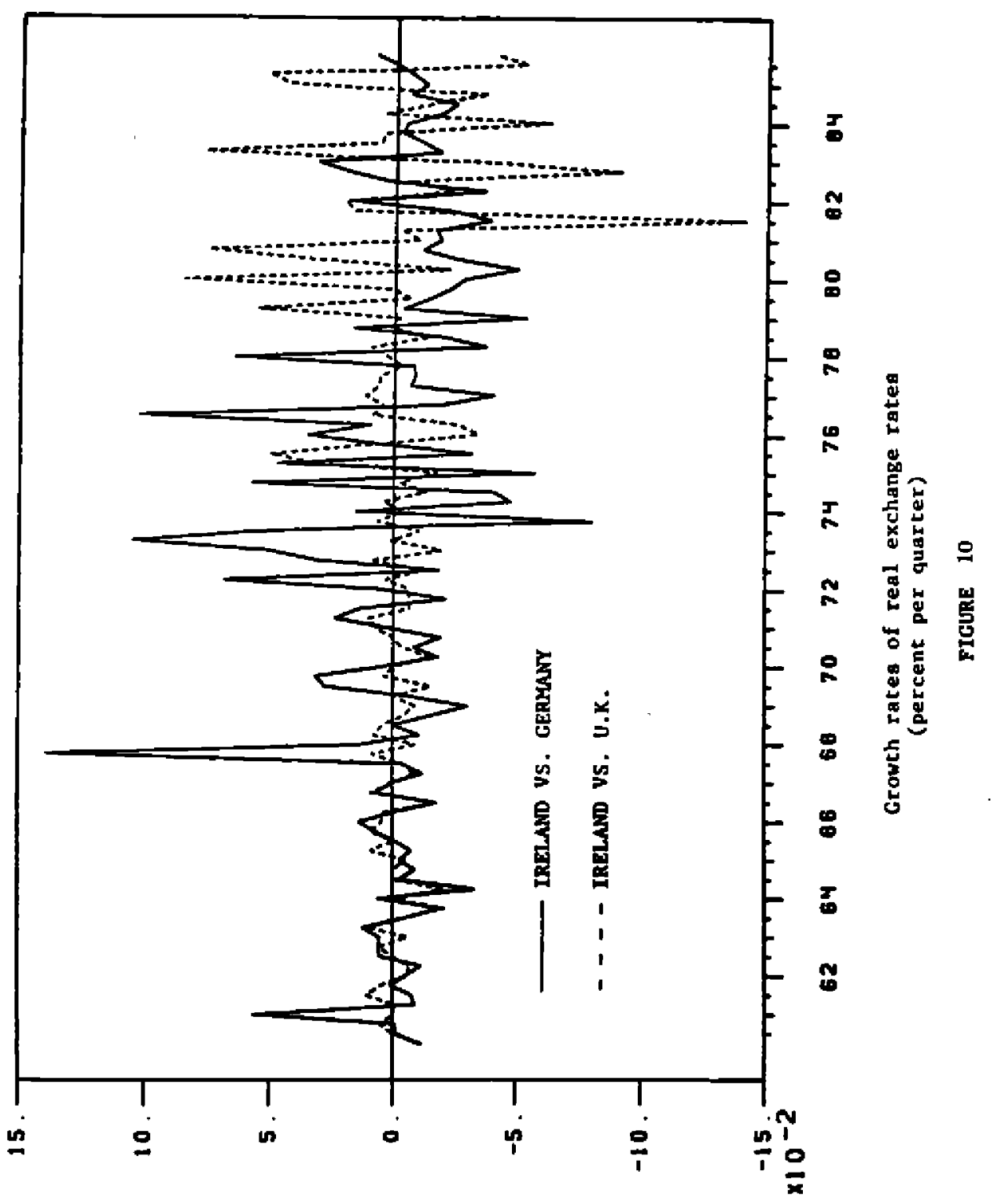




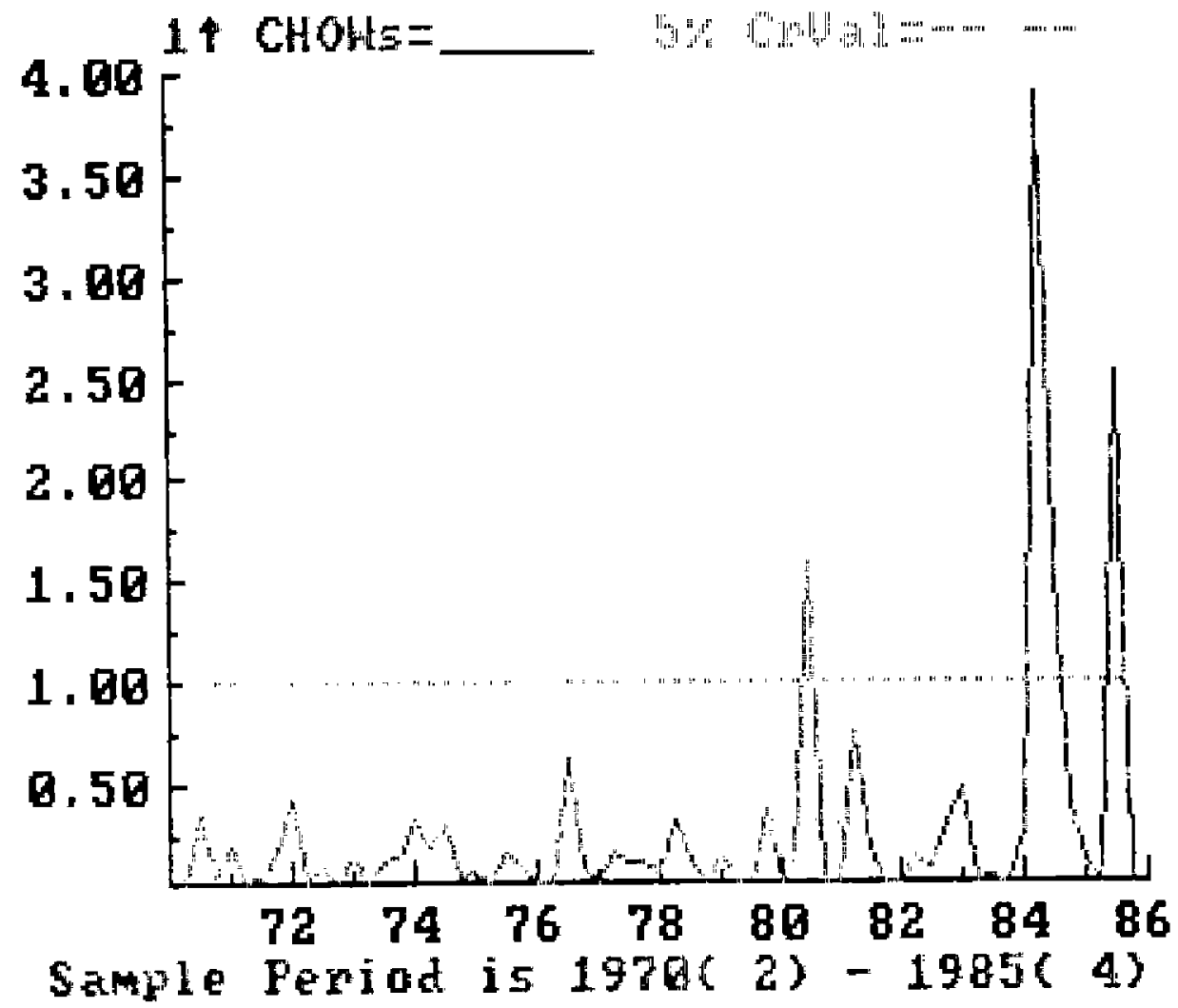

F1gure 11

Sequence of Test Statistics, Relative to .05 Crftical Value, for Hypothesis of No Structural Change in Felative IF: IrelandGermany 
LOG LIKELIHOOD FOR DATE OF ONE SHITCH HIIH CHANGE JK PROCESS: DIFEERENCE IN GROHIH RATES OF IP: IRELAAI - UR

205.0

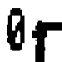

302.5

606

195.0

192,5

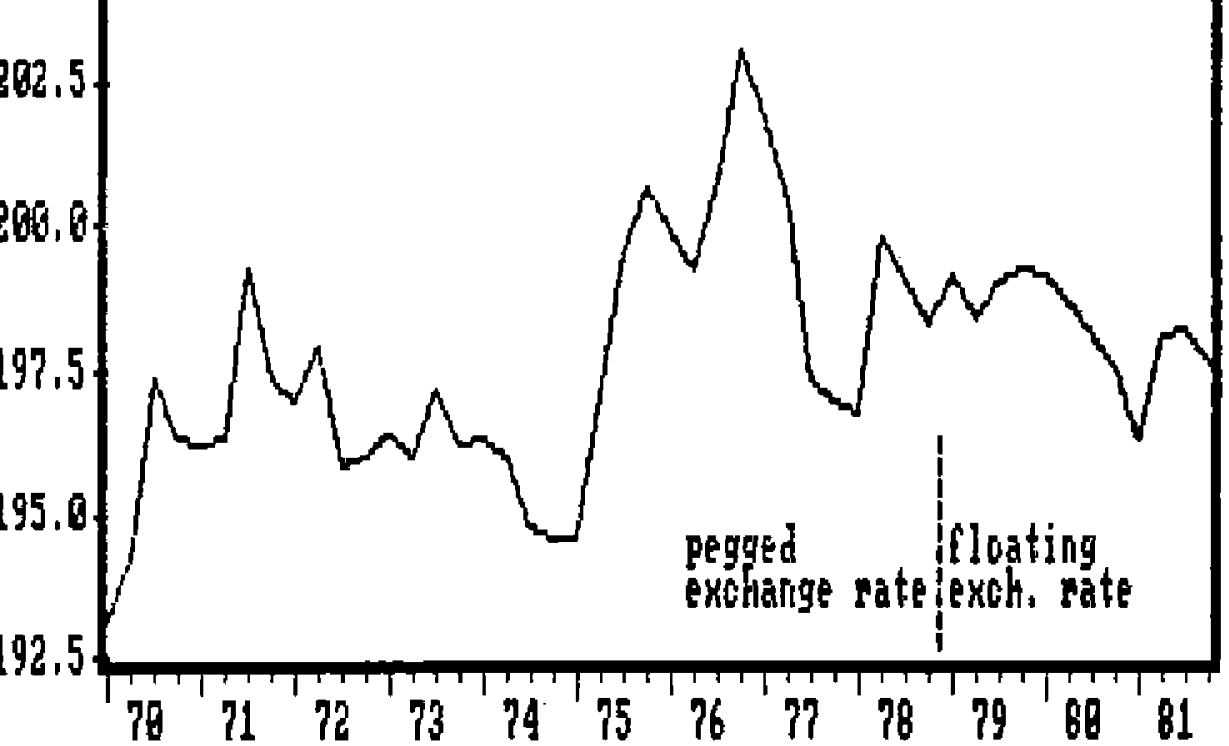

— LOC LIKELIHOOD

Flgure 12 


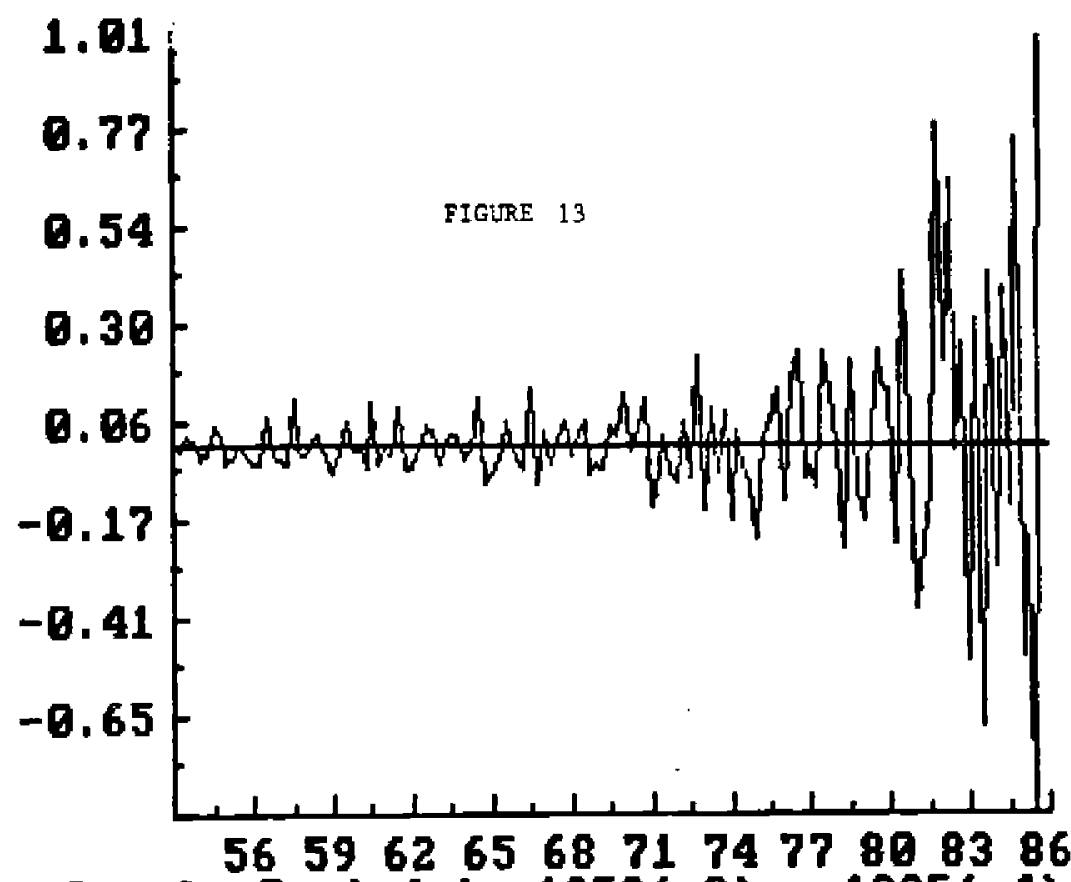

Sample Period is $1953(2)-1985(4)$

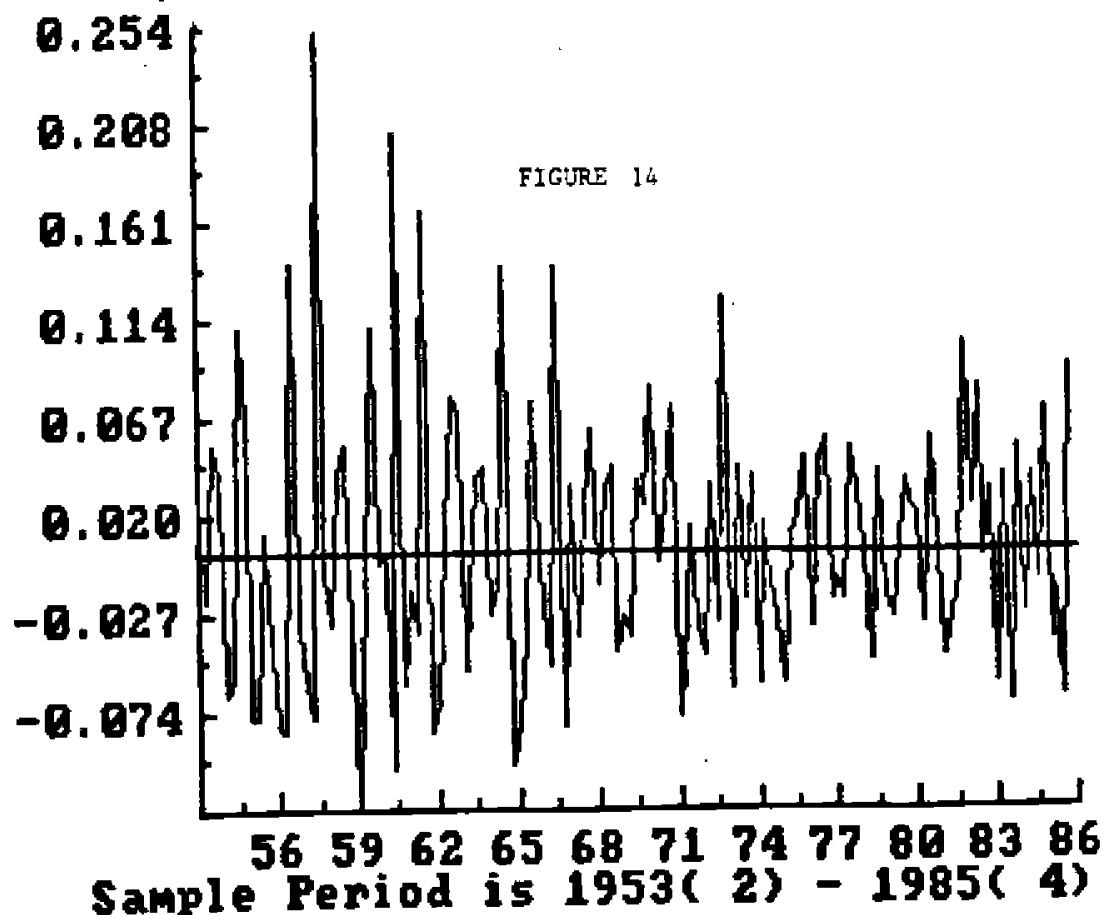

